\title{
Influence of benthic macrofauna community shifts on ecosystem functioning in shallow estuaries
}

\section{Erik Kristensen *, Matthieu Delefosse, Cintia O. Quintana, Mogens R. Flindt and Thomas Valdemarsen}

Department of Biology, University of Southern Denmark, Odense, Denmark

\section{Edited by:}

Christos Dimitrios Arvanitidis, Hellenic Centre for Marine

Research, Greece

\section{Reviewed by:}

Nafsika Papageorgiou, Hellenic

Centre for Marine Research, Greece

Matthias Obst, University of

Gothenburg, Sweden

Christos Dimitrios Arvanitidis,

Hellenic Centre for Marine

Research, Greece

Theodoros Kevrekidis, Democritus

University of Thrace, Greece

\section{${ }^{*}$ Correspondence:}

Erik Kristensen, Department of

Biology, University of Southern

Denmark, Campusvej 55,

5230 Odense, Denmark

e-mail: ebk@biology.sdu.dk
We aim at identifying how ecosystem functioning in shallow estuaries is affected by rapid shifts in benthic fauna communities. We use the shallow estuary, Odense Fjord, Denmark, as a case study to test our hypotheses that (1) shifts in benthic fauna composition and species functional traits affect biogeochemical cycling with cascading effects on the ecological functioning, which may (2) modulate primary productivity in the overlying water column with feedbacks to the benthic system. Odense Fjord is suitable because it experienced dramatic shifts in benthic fauna community structure from 1998 to 2008. We focused on infaunal species composition and functional traits with emphasis on three dominating burrow-dwelling polychaetes: the native Nereis (Hediste) diversicolor and Arenicola marina, and the invasive Marenzelleria viridis. The impact of functional traits in the form of particle reworking and ventilation on biogeochemical cycles, i.e., sediment metabolism and nutrient dynamics, was determined from literature data. Historical records of summer nutrient levels in the water column of the inner Odense Fjord show elevated concentrations of $\mathrm{NH}_{4}^{+}$and $\mathrm{NO}_{3}^{-}$(DIN) during the years 2004-2006, exactly when the $N$. diversicolor population declined and $A$. marina and $M$. viridis populations expanded dramatically. In support of our first hypothesis, we show that excess $\mathrm{NH}_{4}^{+}$ delivery from the benthic system during the $A$. marina and $M$. viridis expansion period enriched the overlying water in DIN and stimulated phytoplankton concentration. The altered benthic-pelagic coupling and stimulated pelagic production may, in support of our second hypothesis, have feedback to the benthic system by changing the deposition of organic material. We therefore advice to identify the exact functional traits of the species involved in a community shift before investigating its impact on ecosystem functioning. We also recommend studying benthic community shifts in shallow environments to obtain sufficient knowledge about the drivers and controls before exploring deep-water environments.

Keywords: infaunal polychaetes, sediment biogeochemistry, bioturbation, benthic metabolism, nutrient cycling, functional trait, benthic-pelagic coupling

\section{INTRODUCTION}

Ecosystem functioning is defined as the transfer of matter and energy through various levels of biological organization (Bonsdorff et al., 1995; Hooper et al., 2005; Boero and Bonsdorff, 2007). These involve primary production, secondary production, and decomposition, where essential nutrients basically are consumed by primary producers and recycled by microbially mediated biogeochemical processes. All processes and organisms are nevertheless essential for the functioning of ecosystems and they are deeply interconnected. The exchange of particulate and dissolved nutrients between sediment and water, i.e., benthic-pelagic coupling, is particularly important for the functioning of shallow coastal and estuarine ecosystems (Brigolin et al., 2011; Hochard et al., 2012; Brady et al., 2013). A key driver for benthic-pelagic coupling is the composition of benthic fauna communities, since various species have distinct and often widely different functional traits (Braeckman et al., 2010; Dornhoffer et al., 2012;
Kristensen et al., 2012). Accordingly, we propose three basic features of benthic communities for the control of benthic-pelagic coupling in coastal ecosystems (sensu Boero, 1999); (1) species composition (diversity, abundance and interactions); (2) species functional traits (production, bioturbation, and transfers); and (3) species impact on biogeochemical cycles (nutrient exchange). The specific role these three features in any coastal ecosystem is unique because their expression is based on the actual state of the involved organisms and associated processes exposed to the environmental conditions prevailing in that ecosystem, which are unlikely to be exactly similar somewhere else (Pérez-Ruzafa et al., 2011; Norkko et al., 2013).

It is also unlikely that the functioning of any coastal ecosystem will remain unchanged through time. Temporal variations in e.g., benthic species composition caused by human induced or natural perturbations leading to changes in dominant functional traits have strong implications for the biogeochemical functioning of 
ecosystems (Bulling et al., 2006; Ieno et al., 2006; Solan et al., 2006). Thus, changes in environmental conditions (e.g., salinity, temperature) and eu- or oligotrophication status combined with arrival of new species may lead to unpredictable and rapid expansion of some species and decline or even extinction of other species (Reise et al., 2006; Crowe et al., 2013). If changes in community structure are large, sudden and long-lasting, a regime shift have occurred (Hare and Mantua, 2000; Scheffer and Carpenter, 2003; Beaugrand, 2004). van Nes et al. (2007) argued that communities may have more than one stable state and that transition to other contrasting states may occur if environmental conditions change only gradually or if there is a short-term external disturbance. Petersen et al. (2008) demonstrated a distinct regime shift in the nutrient-stressed estuary, Ringkøbing Fjord, Denmark. They found that a small change in salinity facilitated by modified sluice management caused a sudden change in species composition with new recruitment and rapid population growth of the suspension-feeding clam, Mya arenaria. This resulted in a dramatic change from a nutrient controlled state with turbid water and pelagic turnover, to a suspension-feeder controlled state with clear water caused by strong benthic-pelagic coupling. The functional traits of the new population of suspension-feeding clams were in this case essential for the shift in ecosystem functioning.

When transitions occur repeatedly from one state to the other over shorter time-scales they cannot be denoted regime shifts as such, but the associated change in ecosystem functioning may very well illustrate the impact of a regime shift. However, only few studies (e.g., Petersen et al., 2008) have examined in detail how large shifts in abundance of fauna and alternative functional traits affect benthic-pelagic coupling and thus the overall functioning of shallow coastal ecosystems. This is somewhat understandable because a considerable number of biological, chemical, and physical parameters have to be measured with a perfect timing and frequency to capture an unpredictable shift event. Some studies have registered distinct regime shifts in benthic fauna composition (e.g., Eriksson et al., 2010; Spencer et al., 2010), but the associated impact of functional traits on benthic-pelagic coupling and the exact mechanisms for the changes are rarely identified. Conversely, other studies have provided reliable estimates on how functional traits of benthos affect benthic-pelagic coupling in the form of particle capture by suspension feeding or bioturbation-driven nutrient release to the overlying water and related it to phytoplankton dynamics (e.g., Doering, 1989; Grenz et al., 2000; Grall and Chauvaud, 2002). However, these studies are rarely directed to capture the impact of major shifts in fauna composition and associated ecosystem effects.

In this study we aim at identifying how ecosystem functioning in shallow estuaries is affected when benthic-pelagic coupling is altered due to rapid and large shifts in benthic fauna communities. We particularly try to elucidate the direct link between ecosystem functioning and functional traits of the benthic fauna (e.g., sediment reworking and ventilation). We use the shallow estuary, Odense Fjord, Denmark, as a case study because the robust historical monitoring data from this estuary have captured significant changes in benthic fauna composition. Together with detailed knowledge of underlying mechanisms and functional traits of the involved benthic fauna species, we provide reliable evidence for the impact of changing benthic communities on past and present ecosystem functioning in this area. We hypothesize that (1) shifts in benthic fauna composition and species functional traits affect biogeochemical cycling with cascading effects on the ecological functioning, which may (2) modulate primary productivity in the overlying water column with feedbacks to the benthic system.

\section{STUDY APPROACH}

We will test our general hypotheses by evaluating available and relevant data on historical environmental trends in our case study area; the shallow estuary, Odense Fjord. These will be combined with knowledge on the functional traits of the dominant benthic fauna. The Odense Fjord estuary is first portrayed with focus on long-term nutrient trends and implications for primary producers. Next, we describe the "species composition" of benthic fauna in the fjord with emphasis on changes and interactions in time and space of three dominant species of burrow dwelling polychaetes, i.e., the native Nereis (Hediste) diversicolor and Arenicola marina, and the invasive Marenzelleria viridis. We then evaluate how their "functional traits" in the form of particle reworking and ventilation/irrigation (sensu Kristensen et al., 2012) modifies "biogeochemical cycles" through sediment metabolism and nutrient dynamics. Finally, we determine the consequences of the functional changes and temporal trends for benthic-pelagic coupling (nutrient and phytoplankton levels). The background data are mostly derived from previously published studies in Odense Fjord combined with published experimental results on the biogeochemical impact of the three polychaetes. The results obtained from the Odense Fjord case study are then used as the evidence for testing our hypotheses and provide the basis for conclusions on how benthic fauna community shifts affect ecosystem functioning in estuaries.

\section{ODENSE FJORD; PAST AND PRESENT NUTRIENT AND FLORA TRENDS}

Odense Fjord is a shallow microtidal estuary, located in the northeastern part of the island of Fyn, Denmark (Figure 1). The estuary covers $62 \mathrm{~km}^{2}$ with an average water depth of 2.2 and a $0.3 \mathrm{~m}$ tidal amplitude. It is divided into an inner and an outer part. The shallow inner fjord ( $0.8 \mathrm{~m}$ average depth), which is the focus area of the case study, comprises $1 / 4$ of the total area and is impacted by freshwater inputs from Odense River and diffusive drainage from land. The outer fjord has a more variable bathymetry $(2.7 \mathrm{~m}$ average depth) and opens to the Kattegat through a narrow opening in the northeast. Salinity varies depending on freshwater input and exchange with the Kattegat typically from 5 to 17 and 15 to 25 in the inner and outer fjord, respectively, with the lowest salinity typically measured during winter (Fyns Amt, 2004). The inner fjord has lowest salinity in the southeastern part due to freshwater drainage from land, while the salinity in the northwestern part is maintained artificially high by discharge of saline cooling water from a power plant (Koed et al., 1997). Sediments in the inner fjord mainly consist of low organic $(<3 \%)$ sand (median grain size around $200 \mu \mathrm{m}$ ), but the deeper areas trap fine particles and form organic-rich $(>10 \%)$ silty sediments (Valdemarsen et al., 2014) (Table 1). 


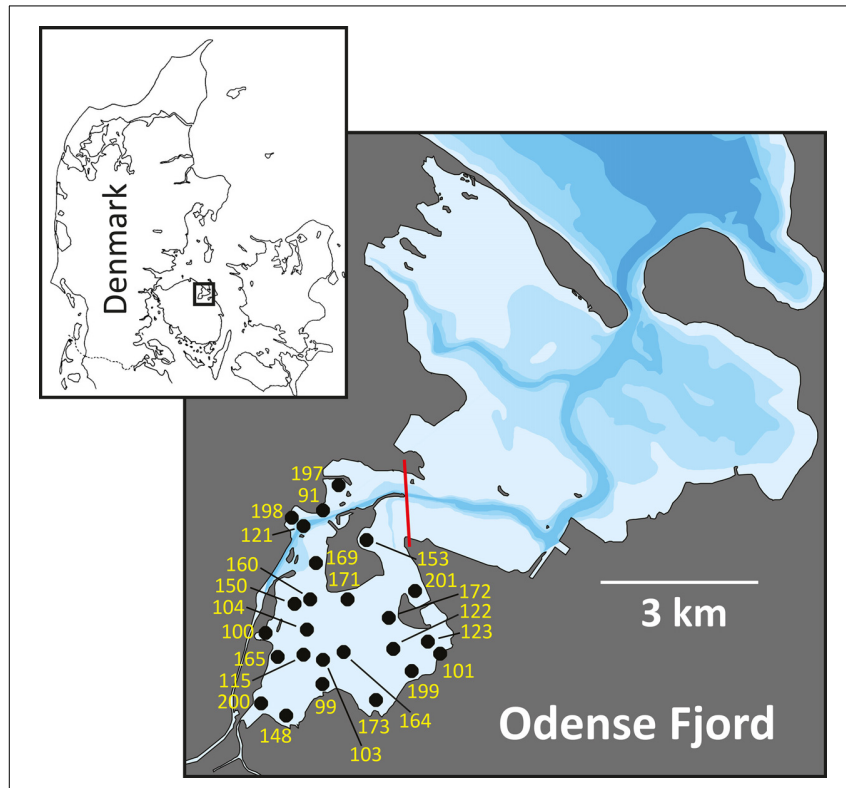

FIGURE 1 | Map of Odense Fjord. The boundary between inner and outer fjord is marked by a red line. All stations used for fauna sampling in the inner fjord are indicated by numbers (excluding the prefix OF).

Table 1 | Key water column and sediment characteristics $(\mathbf{n m}=$ not measured) at representative sediment sampling stations in the inner part of Odense Fjord obtained during summer surveys in 2008 and 2010 (unpublished results).

\begin{tabular}{|c|c|c|c|c|c|}
\hline Station & $\begin{array}{c}\text { Water } \\
\text { depth } \\
(\mathrm{m})\end{array}$ & Salinity & $\begin{array}{c}\text { Organic } \\
\text { content } \\
0-15 \mathrm{~cm}(\% \mathrm{dw})\end{array}$ & $\begin{array}{c}\text { Silt + clay } \\
0-1 \mathrm{~cm} \\
(\% \mathrm{dw})\end{array}$ & Vegetation \\
\hline OF100 & 0.3 & 11 & 1.60 & 2.3 & \\
\hline OF101 & 0.1 & 6 & 1.01 & $\mathrm{~nm}$ & Ruppia, Ulva \\
\hline OF103 & 1.2 & 11 & 1.51 & $\mathrm{~nm}$ & Ruppia, Ulva \\
\hline OF104 & 1.5 & 6 & 3.57 & 13.5 & Ruppia, Zostera \\
\hline OF115 & 1.2 & 12 & 3.47 & $\mathrm{~nm}$ & Ruppia, Ulva \\
\hline OF121 & 3.2 & $\mathrm{~nm}$ & 11.58 & 53.4 & \\
\hline OF122 & 1.2 & 10 & 5.41 & $\mathrm{~nm}$ & Ruppia, U/va \\
\hline OF123 & 1.2 & 9 & 0.96 & $\mathrm{~nm}$ & Ruppia, Ulva \\
\hline OF160 & 0.2 & $\mathrm{~nm}$ & 0.60 & 7.0 & \\
\hline OF164 & 1.2 & 11 & 0.52 & 18.6 & Ruppia, U/va \\
\hline OF169 & 0.2 & $\mathrm{~nm}$ & 0.82 & $\mathrm{~nm}$ & \\
\hline
\end{tabular}

The macrophyte species are Ruppia maritima, Ulva lactuca, and Zostera marina.

Odense Fjord has a large catchment area $\left(1046 \mathrm{~km}^{2}\right)$, resulting in substantial nutrient loading primarily due to agricultural runoff. The loading was $\sim 3000 \mathrm{t} \mathrm{N}$ year $^{-1}$ and $\sim 300 \mathrm{t} \mathrm{P}$ year $^{-1}$ prior to 1990, but after the implementation of several water action plans during the last 20 years nutrient loading has gradually been reduced to the present levels of $<2000 \mathrm{t} \mathrm{N}$ year ${ }^{-1}$ and $\sim 50 \mathrm{t}$ $\mathrm{P}_{\text {year }}{ }^{-1}$ (Petersen et al., 2009). As a consequence, the nutrient concentrations in the fjord diminished, now typically rendering dissolved inorganic phosphorus ( $\left.\mathrm{DIP}=\mathrm{PO}_{4}^{3-}\right)$ and dissolved inorganic nitrogen ( $\mathrm{DIN}=\mathrm{NH}_{4}^{+}$and $\mathrm{NO}_{3}^{-}$) limiting factors for
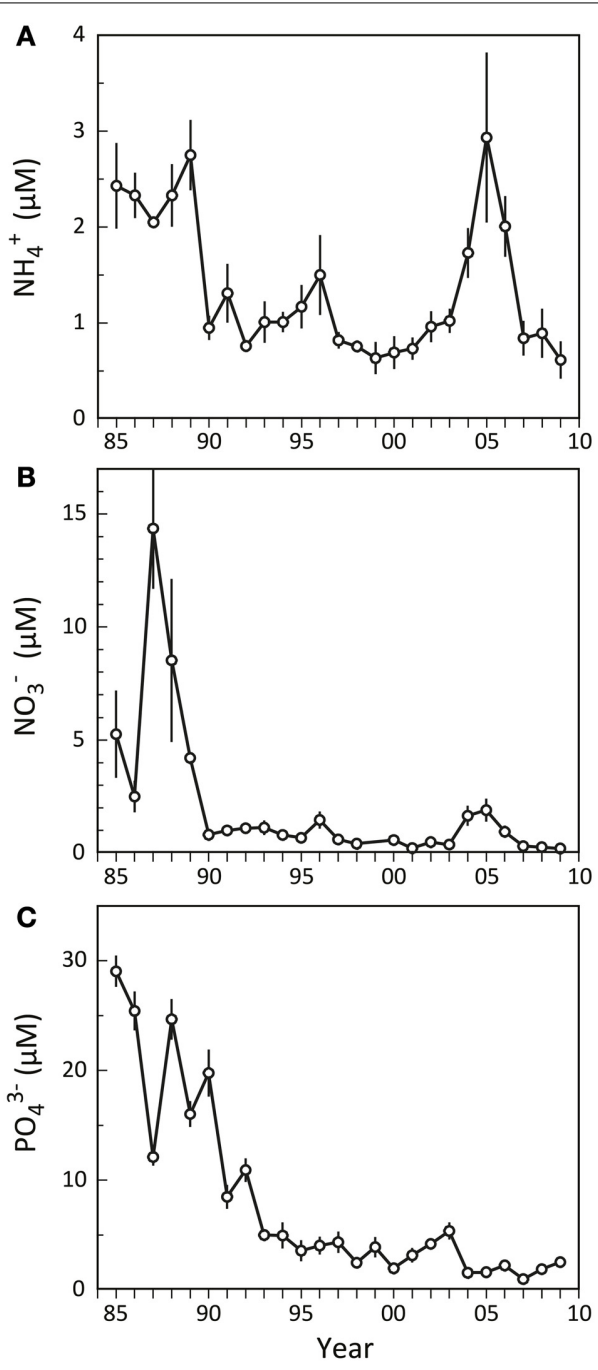

FIGURE 2 | Summer nutrient levels (A: $\mathrm{NH}_{4}^{+}$; $\mathrm{B}: \mathrm{NO}_{3}^{-} ; \mathrm{C}: \mathrm{PO}_{4}^{3-}$ ) in the water column of the inner part of Odense Fjord from 1985 to 2009. Samples were taken in June-August at station OF122. Error bars indicate $\pm S E[n=3$ (1985-1992); 7 (1993-1997); 12 (1998-2001); 26 (2002-2006); 10 (2007-2009)] (data kindly provided by The Danish Nature Agency).

primary production in spring and summer, respectively (Fyns Amt, 2004). Nutrient levels were generally high in the inner fjord before 1990 (Figure 2), with summer $\mathrm{NO}_{3}^{-}$and $\mathrm{PO}_{4}^{3-}$ exhibiting considerable variation among and within years showing concentrations ranging from 2 to $30 \mu \mathrm{M}$ (Figures $2 \mathrm{~B}, \mathrm{C}$ ). $\mathrm{NH}_{4}^{+}$, on the other hand, remained more stable at $2-3 \mu \mathrm{M}$ (Figure 2A). A few years after implementation of the first Danish Action Plan for the Aquatic Environment in 1987 (Kronvang et al., 2008), the summer nutrient levels in the inner part of Odense Fjord decreased and showed much lower year to year variations. $\mathrm{NH}_{4}^{+}$ and $\mathrm{NO}_{3}^{-}$rapidly stabilized around 1 and $0.5 \mu \mathrm{M}$, respectively, except for a minor increasing trend in 1996 and a pronounced elevation in 2004-2006. During this latter period $\mathrm{NH}_{4}^{+}$and $\mathrm{NO}_{3}^{-}$reached levels of 3 and $2 \mu \mathrm{M}$. No such markedly elevated summer concentrations were evident for $\mathrm{PO}_{4}^{3-}$ that otherwise exhibited a continued gradual decrease during the entire period 


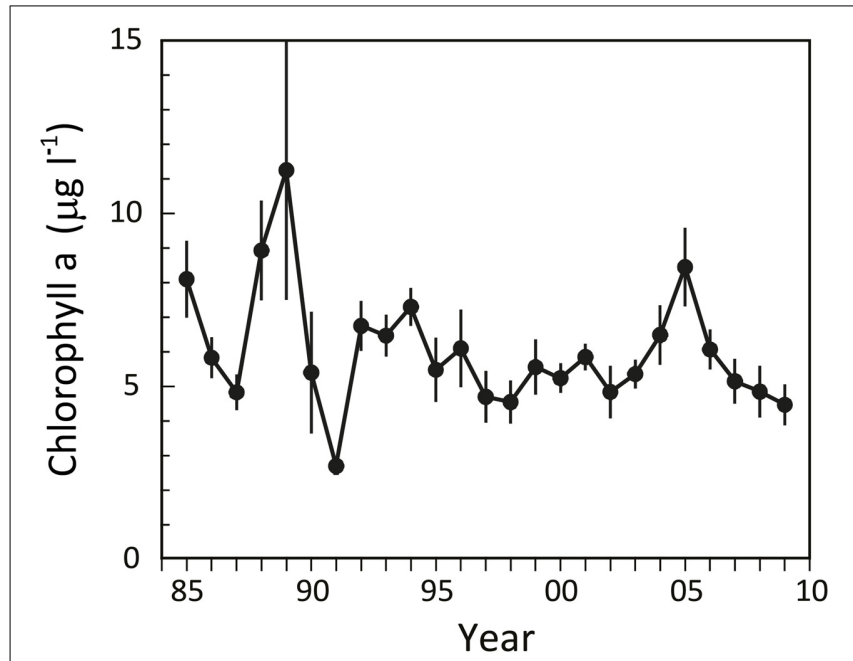

FIGURE 3 | Summer Chlorophyll a levels in the water column of the inner part of Odense Fjord from 1985 to 2009. Samples were taken in June-August at station OF122. Error bars indicate \pm SE $[n=3$ (1985-1992); 7 (1993-1997); 12 (1998-2001); 26 (2002-2006); 10 (2007-2009)] (data kindly provided by The Danish Nature Agency).

after 1990, reaching a more or less constant level of 1-2 $\mu \mathrm{M}$ after 2003.

Currently, the macrophyte vegetation in the inner fjord consists mainly of the seagrass, Ruppia maritima, and the macroalgae, Ulva lactuca (Riisgård et al., 2008), with scattered eelgrass (Zostera marina) occurrence in the northern part. Surveys of submerged macrophytes in the 1980s and early 1990s showed that the inner fjord was strongly dominated by U. lactuca, while the distribution of $R$. maritima was limited by light availability, competition from U. lactuca (e.g., Hauxwell et al., 2001) and hypoxic events (e.g., Greve et al., 2005). However, the lowered nutrient loading in the 1990s improved the water quality, as evidenced by higher water transparency and recession of $U$. lactuca abundance (Fyns Amt, 2004; Petersen et al., 2009). R. maritima has since then spread widely and covers today about $50 \%$ of the inner fjord (Petersen et al., 2009).

The phytoplankton response to lower summer nutrient concentrations after 1990 was moderate. The water column "Chlorophyll a" levels, as a measure of phytoplankton biomass, varied considerably before 1990 with summer concentrations ranging from 5 to almost $15 \mu \mathrm{g} \mathrm{l}^{-1}$ (Figure 3), but not in phase with nutrient availability. Subsequently, more stable levels around $5 \mu \mathrm{g} \mathrm{l}^{-1}$ were reached after the mid 1990s, except for a pronounced increase during the period 2004-2006 with a peak of $8.5 \mathrm{Mgl}^{-1}$ in 2005 This increase in Chlorophyll a was apparently a response to the simultaneous increase in DIN (Figure 2), pointing to the fact that the inner fjord is nitrogen limited during summer, as also indicated from a generally very low DIN:DIP ratio of $\sim 1$.

\section{COMPOSITION OF BENTHIC FAUNA: SPATIAL AND TEMPORAL PATTERNS}

The estuarine environment in the inner part of Odense Fjord is stressful for benthic fauna. Relatively few species are adapted to withstand the highly variable environmental conditions with
Table 2 | Range and area-wide average $( \pm S D)$ density and biomass of Nereis diversicolor, Arenicola marina and Marenzelleria viridis obtained during 2008 and 2010 surveys in the inner part of Odense Fjord (data derived from Delefosse and Kristensen, 2012 and Kristensen et al., 2013).

\begin{tabular}{lcc}
\hline & \multicolumn{2}{c}{ Inner fjord (n= 25) } \\
\cline { 2 - 3 } & Range & average \pm SD \\
\hline DENSITY (ind $\mathbf{~}^{\mathbf{- 2}}$ ) & $14-3013$ & $1244 \pm 957$ \\
N. diversicolor & $0-57$ & $5 \pm 13$ \\
A. marina & $0-1174$ & $92 \pm 245$ \\
M. viridis & & 1341 \\
\hline Total & & \\
BIOMASS (g ww $\mathbf{~ m}^{\mathbf{- 2}}$ ) & $0.7-362.9$ & $99.6 \pm 85.5$ \\
N. diversicolor & $0.0-82.3$ & $11.8 \pm 26.2$ \\
A. marina & $0.0-63.8$ & $7.7 \pm 16.7$ \\
M. viridis & & \\
\hline
\end{tabular}

Total 119

dramatic and unpredictable changes in, e.g., salinity, temperature and oxygen conditions (Ysebaert et al., 2005; Delefosse et al., 2012). Recent surveys (2008-2010), based on 25 sampling stations (Figure 1), have shown that the benthic fauna in the inner fjord is characterized by high abundance of opportunistic species like the oligochaete Tubificoides benedii (on average 25\% of the total), the polychaete Pygospio elegans (20\%), gastropods from the Hydrobiidae family (20\%), the crustacean Corophium volutator (10\%), and the polychaete $N$. diversicolor (10\%), while the polychaetes Marenzelleria viridis (5\%) and Arenicola marina $(<1 \%)$ are less abundant. The above-mentioned species together constitute $>90 \%$ of the total infaunal abundance (Delefosse et al., 2012; Kristensen et al., 2013), while the latter three species account for $>75 \%$ of the total biomass.

The three polychaetes, $N$. diversicolor, A. marina, and $M$. viridis, are chosen as key species in this study, because they are conspicuous and dominating bioturbators in the inner Odense Fjord. They are, in contrast to the other more abundant infaunal species, large bodied (Table 2) with substantial capacity for sediment reworking and burrow ventilation (Riisgård and Banta, 1998; Quintana et al., 2011; Delefosse and Kristensen, 2012). Our focus on these species is corroborated by Norkko et al. (2013), who showed that large bodied infaunal species in natural communities have proportionally higher impact on ecosystem function (e.g., energy flow and nutrient cycling) than more abundant small bodied species.

Nereis diversicolor is common throughout most of the sandy to muddy inner fjord sediments, with abundances ranging between 1000 and 3000 ind $\mathrm{m}^{-2}$ or 100 and $360 \mathrm{~g} \mathrm{ww} \mathrm{m}^{-2}$ (Delefosse et al., 2012; Table 2; Figure 4). However, its abundance in the northern part is generally below 100 ind $\mathrm{m}^{-2}$ or $10 \mathrm{~g} \mathrm{ww} \mathrm{m}^{-2}$, except for intertidal and low saline refuges. A. marina primarily occurs in organic-poor sandy areas of the central inner fjord (Figure 4). Its population size rarely exceeds 50 ind $\mathrm{m}^{-2}$, which is much lower than for the other common species, but its population biomass is often high (more than $100 \mathrm{~g} \mathrm{ww} \mathrm{m}^{-2}$ ) due to its very large body 


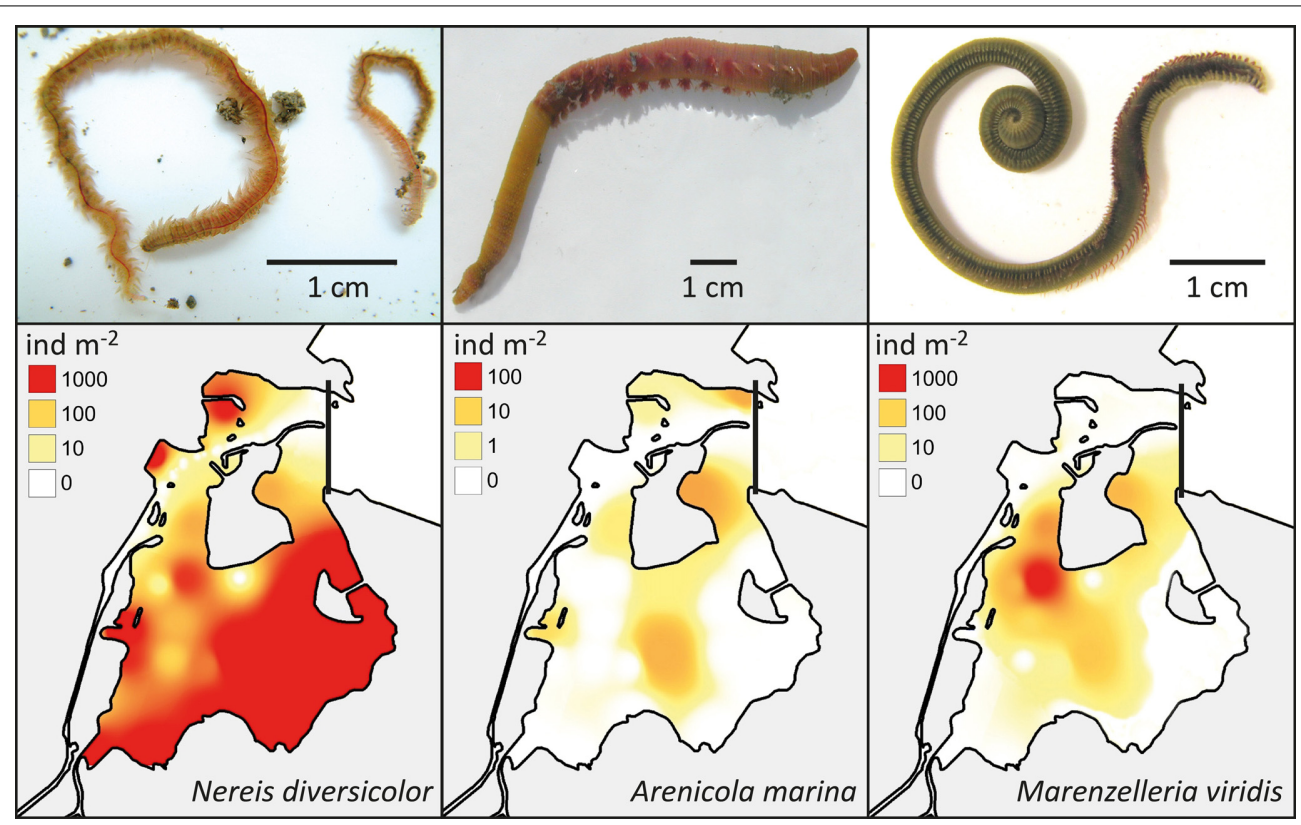

FIGURE 4 | Upper panel: The visual appearance of Nereis diversicolor, Arenicola marina and Marenzelleria viridis (Photos by E. Kristensen). Lower panel: The distribution and abundance of the three polychaetes in the inner part of Odense Fjord. Data was obtained from a survey conducted in 2008 and 2010 (Delefosse et al., 2012). size. The invasive $M$. viridis was first observed in Odense Fjord in 2002 and reached its widest distribution around 2004 where it was observed on $75 \%$ of the monitoring stations (Delefosse et al., 2012). M. viridis was in 2008-2010 present at 50\% of the stations in the inner fjord; most abundant in the northwestern part (up to 1200 ind $\mathrm{m}^{-2}$ or $64 \mathrm{~g} \mathrm{ww} \mathrm{m}^{-2}$ ) (Figure 4). Neither A. marina nor $M$. viridis have been observed at the 7 stations with lowest salinity in the southeastern part of the inner fjord.

Long-term analyses in the inner part of Odense Fjord revealed shifts in benthic fauna composition during the last 10-20 years following the reductions in nutrient loading and Ulva lactuca coverage (Delefosse et al., 2012). The most pronounced change was a dramatic decrease in abundance of $N$. diversicolor between 1997 and 2004 in areas newly colonized by A. marina and $M$. viridis (Figure 5, Station OF115). It is unclear whether the decline in $N$. diversicolor was caused by the arrival of $M$. viridis, but limited evidence so far obtained suggests a negative interaction between these two species (Essink, 1999; Kotta et al., 2006; Delefosse et al., 2012). However, the pronounced inverse pattern between A. marina and $N$. diversicolor biomass suggests that the former species is most likely responsible for the recession of the latter. Antagonism between these two species has previously been attributed to the vigorous sediment mixing and strong disturbance induced by $A$. marina and to competition for food (Flach, 1992; Zipperle and Reise, 2005; Volkenborn and Reise, 2006). In contrast, a positive relationship between $A$. marina and M. viridis was reported by Delefosse et al. (2012). It is puzzling how $M$. viridis is able to thrive under the strong physical disturbance regime of $A$. marina. A similar positive interaction between A. marina and the polychaete Scoloplos armiger in more saline environments is probably mediated by the less harsh chemical conditions (e.g., sulfide) near A. marina burrows (Volkenborn and Reise, 2006).

The incidences of $A$. marina expansion in the inner Odense Fjord are difficult to explain. The first expansion occurred around 1996 at the middle station OF115, and then on a broader scale 7 years later; extending into the neighboring stations (Figure 5). This was probably facilitated by improved environmental conditions with diminished $U$. lactuca cover, lower sediment organic content and higher oxygen availability. However, the timing of A. marina recruitment may be triggered by markedly higher salinity than normal (12-18 vs. 10-15) in the inner part of the estuary during 2003 owing to low precipitation and excessive inflow of seawater into the Baltic Sea that year (Fyns Amt, 2004; Blank et al., 2008). Similar salinity changes have caused abrupt community alterations in other shallow coastal areas (Zipperle and Reise, 2005; Petersen et al., 2008). A. marina survives well at salinities as low as 10-12 (Shumway and Davenport, 1977; Reitze and Schöttler, 1989), but requires somewhat higher salinity for reproduction. Thus, the inner part of Odense Fjord is close to its lower salinity limit (Table 1). Hence, the one-year high salinity levels (>15) in 2003 (and probably locally also at station OF115 during the dry year of 1996; Fyns Amt, 1997) may have promoted successful settling of A. marina larvae in areas devoid of $U$. lactuca. The subsequent decline in A. marina abundance after 3-4 years corresponds to the typical longevity of this species (Beukema and De Vlas, 1979) and strongly indicates a very successful settling with subsequent dominance of one generation. Two consecutive generations may have been present at station OF115 from 1996 to 2007 (Figure 4). The salinity changes were apparently not sufficient to allow $A$. marina colonization at the low saline stations in the southeastern part. 


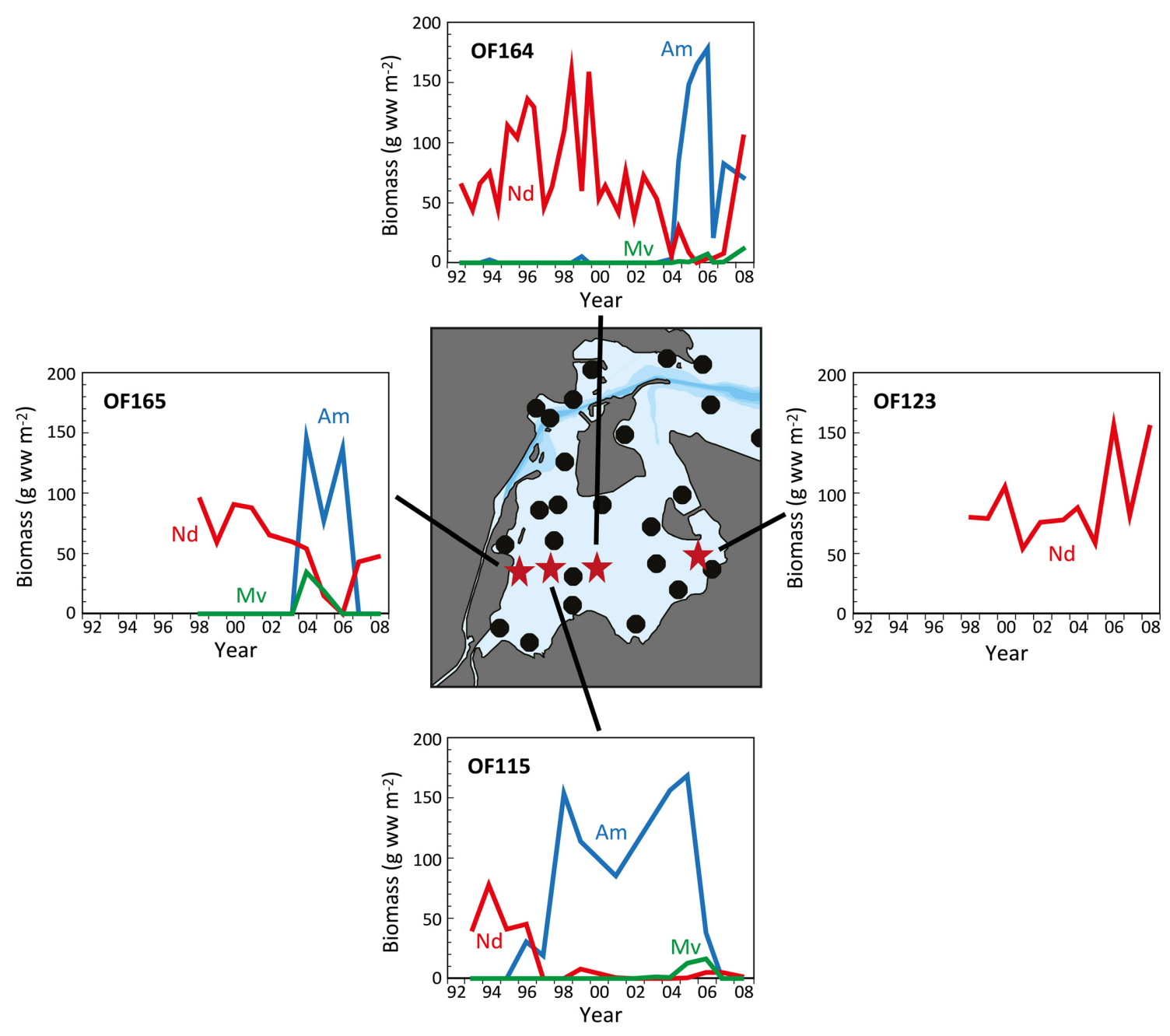

FIGURE 5 | The temporal development in biomass of Nereis diversicolor (Nd), Arenicola marina (Am), and Marenzelleria viridis (Mv) at 4 representative stations (OF115 from 1993 to 2008; OF123 from 1998 to 2008; OF164 from 1992 to 2008; and OF165 from
1998 to 2008) in the inner part of Odense Fjord. The central map indicates the position of sampling stations with red stars representing those shown in the graphs (data kindly provided by The Danish Nature Agency).

\section{FUNCTIONAL TRAITS OF THE BENTHIC COMMUNITY: PARTICLE REWORKING AND VENTILATION/IRRIGATION}

The functional traits of infaunal polychaetes are related to their particle reworking and burrow ventilation capacity, which in turn affect transport conditions and biogeochemistry of the sediment and consequently solute exchange between sediment and overlying water (Kristensen et al., 2012). Active particle reworking includes burrowing, construction and maintenance of burrows as well as ingestion and defecation of particles. Burrow ventilation occurs when animals flush their open- or blind-ended burrows with overlying water for respiratory and feeding purposes, and causes rapid exchange of solutes between sediment porewaters and the overlying water (Kristensen, 2001; Shull et al., 2009).

Particle reworking by $N$. diversicolor and $M$. viridis belongs to the category "gallery biodiffusors" (Kristensen et al., 2012; Lindqvist et al., 2013). They displace particles downward at an exponentially decreasing rate with depth in the sediment. The transport of particles is random and local over short distances resulting in a down-gradient vertical transport of particles analogous to molecular diffusion. A. marina is one of the most conspicuous and intense particle reworkers belonging to the category "upward conveyors" in shallow and intertidal sandy sediments (Valdemarsen et al., 2011; Kristensen et al., 2012). They transport particles from deep horizons to the sediment surface. The particles are actively moved non-locally upwards either when passing through the gut or when subsided material is ejected by water bursts during clearance of the ingestion cavity. According to published data, weight-specific reworking by $A$. marina at $15^{\circ} \mathrm{C}$ is 4 and 27 times more intense than for $N$. diversicolor and M. viridis, respectively (Table 3 ). A rough quantitative description of the average reworking on an ecosystem scale can be obtained when the long-term analysis of biomass dynamics of the three polychaetes at stations OF115, OF123, OF164, and OF165 (Figure 5; Delefosse et al., 2012) is assumed representative for the entire 
inner Odense Fjord. We focus on the period from 1998 to 2008 where fauna abundances are documented by reliable data. The total reworking capacity by all three species is quite impressive and ranges from 1.5 to $2 \mathrm{~cm} \mathrm{mo}^{-1}$ before the $A$. marina population expansion to more than $4 \mathrm{~cm} \mathrm{mo}^{-1}$ during the expansion. This is equivalent to a total reworking depth of $9-24 \mathrm{~cm}$ during 6 months from April to October where the average in situ water temperature corresponds to that in the experimental studies providing the data $\left(\sim 15^{\circ} \mathrm{C}\right.$, Table 3$)$. Consequently, labile organic particles are rapidly transferred from oxic surface to anoxic subsurface sediment, while refractory subsurface particles are lifted to the oxic sediment surface. Here the organic particles are degraded several fold faster than under anoxic conditions (Kristensen and Holmer, 2001) and are also likely to be lost by erosion (Wendelboe et al., 2013). A. marina was the overall major contributor to ecosystem reworking (Figure 6) due to its high weight-specific reworking activity and large biomass (Table 3 ). Its contribution increased from 60 to $70 \%$ during the pre-expansion period to almost 90\% during its temporary population expansion from 2004 to 2006. The remaining reworking was almost exclusively due to $N$. diversicolor, but with a temporary decline in 2005 corresponding to its diminished population during the A. marina expansion.

The renewal of burrow water through intermittent ventilation by the three burrow-dwelling polychaetes is the driving force for bioirrigation, i.e., enhanced exchange of pore water and associated solutes in the sediment surrounding burrows (Kristensen et al., 2012). The actual extent of bioirrigation depends on the infaunal species in question and the morphology of its burrow (Kristensen, 2001; Shull et al., 2009). The mechanism and rate by which the three examined polychaetes ventilate their burrows are basically different. $N$. diversicolor use muscular sinusoid undulations of the body to ventilate large amounts of water tailwards in its open-ended and U-shaped burrows (Kristensen, 2001; Riisgård and Larsen, 2005). Ventilation of N. diversicolor does not directly induce bioirrigation effects beyond a few $\mathrm{mm}$

Table 3 | Literature values of weight- and time-specific conversion factors of reworking and ventilation for Nereis diversicolor, Arenicola marina, and Marenzelleria viridis at a temperature of $15^{\circ} \mathrm{C}$.

\begin{tabular}{|c|c|c|}
\hline & $\begin{array}{c}\text { Reworking } \\
{\left[\mathrm{mm}(\mathrm{g} \mathrm{ww})^{-1} \mathrm{mo}^{-1}\right]}\end{array}$ & References \\
\hline N. diversicolor & $0.119 \pm 0.041$ & Delefosse and Kristensen, 2012 \\
\hline A. marina & $0.404 \pm 0.037$ & Delefosse and Kristensen, 2012 \\
\hline \multirow[t]{2}{*}{ M. viridis } & $0.015 \pm 0.008$ & Delefosse and Kristensen, 2012 \\
\hline & $\begin{array}{c}\text { Ventilation } \\
{\left[\mathrm{ml}(\mathrm{g} \mathrm{ww})^{-1} \mathrm{~min}^{-1}\right]}\end{array}$ & \\
\hline N. diversicolor & $7.88 \pm 0.63$ & Christensen et al., 2000 \\
\hline A. marina & $0.60 \pm 0.19$ & Riisgård et al., 1996 \\
\hline M. viridis & $0.75 \pm 0.55$ & Quintana et al., 2011 \\
\hline
\end{tabular}

All results are obtained from laboratory experiments at $15^{\circ} \mathrm{C}$. Reworking is presented as reworking depth, while ventilation is given as volume of water pumped. Values are given as mean $\pm S D$. into the sediment surrounding burrows (Nielsen et al., 2004; Wenzhöfer and Glud, 2004; Pischedda et al., 2012). A. marina applies peristaltic body movements to forcefully ventilate water headwards in its blind-ended and J-shaped burrows. Bioirrigation is driven by advective percolation of pore water from the headend of the feeding funnel toward the sediment-water interface. $M$. viridis ventilation depends on ciliary action by the dorsal gills, which forces water tailwards into the blind-ended and I-shaped burrows (Quintana et al., 2011). Bioirrigation around burrows of $M$. viridis is slow, and water percolates radially outwards and upwards in the surrounding sediment to a radius of several $\mathrm{cm}$ around the burrows (Quintana et al., 2011; Jovanovic et al., 2014). The weight-specific burrow ventilation is considerably faster (i.e., 10 times) for $N$. diversicolor than the other two species (Table 3 ). This is not only caused by the easy water passage through the open-ended burrow type, but also a consequence of its ability to perform active suspension-feeding (Riisgård, 1991; Christensen et al., 2000). The estimated temporal variation of total daily ventilation on an ecosystem scale at $\sim 15^{\circ} \mathrm{C}$ from 1998 to 2008 , based on the average population biomass of these three polychaetes in

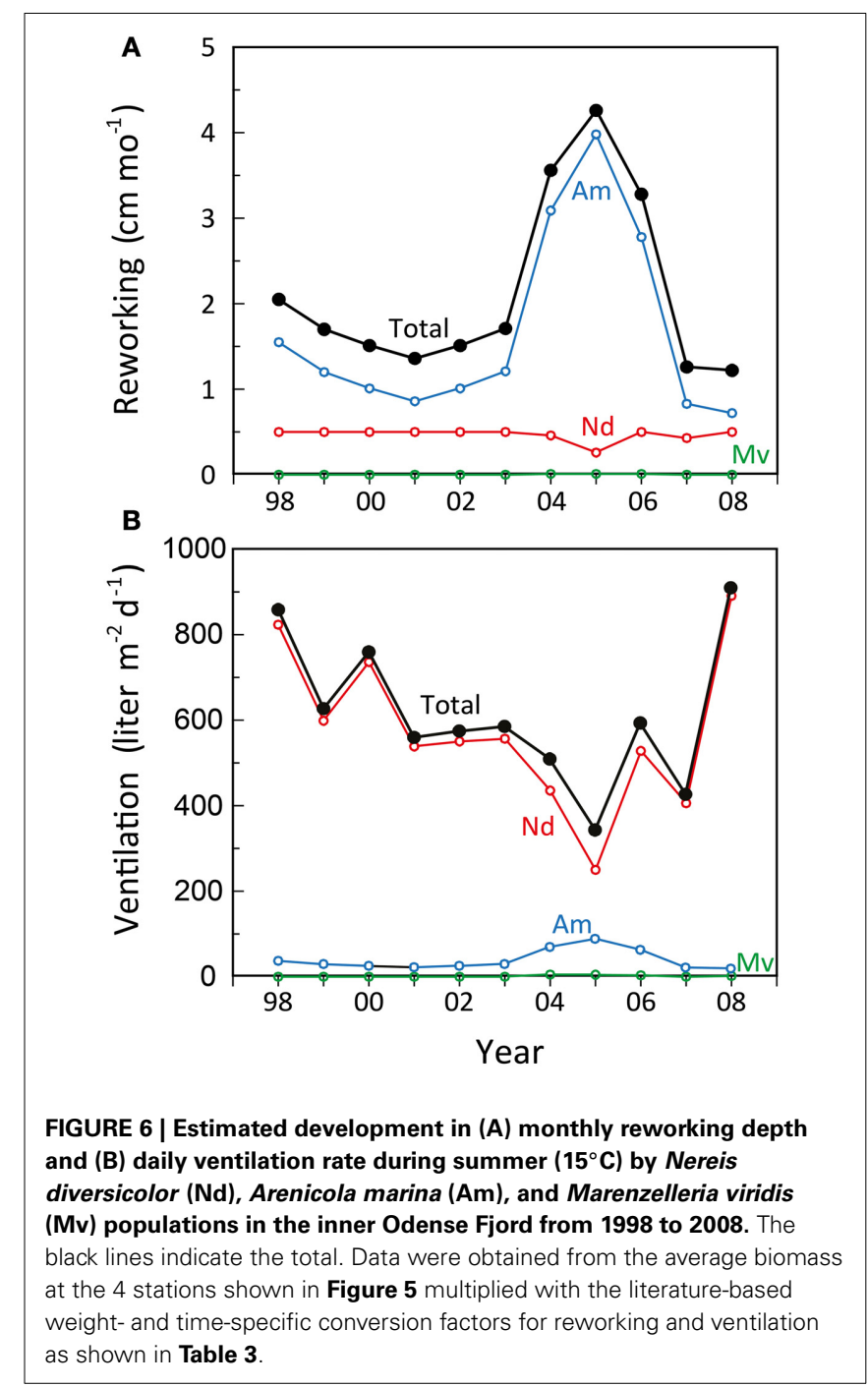


the inner Odense Fjord, ranged from 350 to 900 liter $\mathrm{m}^{-2} \mathrm{~d}^{-1}$ (Figure 6). This is equivalent to $50-100 \%$ of the $0.8 \mathrm{~m}$ water column per day and forms the basis for rapid exchange of particles and solutes between sediment and overlying water. $N$. diversicolor was the major contributor, accounting for $75-98 \%$ of the total community ventilation. The lowest contribution of this species occurred during the period of $A$. marina expansion (i.e., in 2005). This is also the period with highest $M$. viridis contribution, although it barely exceeded $1 \%$ of the total.

\section{BIOGEOCHEMICAL CYCLES: FAUNAL IMPACT ON BENTHIC METABOLISM AND NUTRIENT EXCHANGE}

There is no doubt that functional traits of burrow-dwelling infaunal species enables them to perform bioturbation activities, which may stimulate benthic metabolism through increased organic matter degradation and nutrient exchange (e.g., Banta et al., 1999; Kristensen, 2001; Kristensen et al., 2011). The extent of stimulation is controlled by numerous factors, including quantity and quality of organic matter input to the sediment, as well as the abundance, diversity and behavior of infaunal functional groups (or species) present. The transfer of organic matter between oxic surface and anoxic subsurface sediment through reworking activities leads to overall increased aerobic and anaerobic microbial metabolism (Hulthe et al., 1998; Kristensen and Holmer, 2001). The impact of burrow ventilation depends more on the burrow morphology and bioirrigation pattern than on the actual volume of water ventilated. Accordingly, dynamic bioirrigation forming an oscillating chemical environment around ventilated burrows is the basis for an environment with high microbial metabolism and rapid flushing of solutes (Sun et al., 1993; Aller, 1994; Bertics and Ziebis, 2010). It must be noted, though, that a certain fraction of the faunal-induced stimulation of benthic fluxes (typically $<40 \%$ ) is not microbially derived, but instead a direct result of animal respiration and excretion (Christensen et al., 2000; Quintana et al., 2013).

Published results from laboratory experiments reveal that the average weight- and area-specific enhancement of $\mathrm{O}_{2}$ uptake and $\mathrm{CO}_{2}$ release in sediment inhabited by $N$. diversicolor at $15^{\circ} \mathrm{C}$ is potentially 79 and $102 \mu \mathrm{mol}(\mathrm{g} \mathrm{ww})^{-1} \mathrm{~m}^{-2} \mathrm{~d}^{-1}$, respectively (Table 4). Only few attempts have been made to determine the flux enhancement by A. marina (e.g., Banta et al., 1999; Papaspyrou et al., 2007). The available data indicate that this species has considerably higher capacity to increase $\mathrm{O}_{2}$ and $\mathrm{CO}_{2}$ fluxes than $N$. diversicolor, attaining average weight- and areaspecific enhancements at $15^{\circ} \mathrm{C}$ of 331 and $412 \mu \mathrm{mol}(\mathrm{g} \mathrm{ww})^{-1}$ $\mathrm{m}^{-2} \mathrm{~d}^{-1}$, respectively (Table 4). Downward ventilation in the tail gallery of $A$. marina burrows forces water rich in $\mathrm{O}_{2}$ into the deep sediment surrounding the feeding pocket where it drives efficient aerobic microbial respiration, while upward advection through the feeding funnel flushes generated $\mathrm{CO}_{2}$ out of the sediment. No such strong advective bioirrigation occurs in the open-ended burrows of $N$. diversicolor, where solute gradients and fluxes are mostly controlled by radial diffusion across the burrow wall (Kristensen and Hansen, 1999). M. viridis also augment weight- and area-specific fluxes of $\mathrm{O}_{2}$ and $\mathrm{CO}_{2}$ substantially, reaching potential values at $15^{\circ} \mathrm{C}$ of 345 and $420 \mu \mathrm{mol}(\mathrm{g} \mathrm{ww})^{-1}$ $\mathrm{m}^{-2} \mathrm{~d}^{-1}$, respectively (Table 4 ). This is considerably more than
Table 4 | Literature values of weight-, area-, and time-specific conversion factors of flux enhancement by Nereis diversicolor, Arenicola marina, and Marenzelleria viridis.

\begin{tabular}{|c|c|c|}
\hline & $\begin{array}{l}\mathrm{O}_{2} \text { flux enhancement } \\
\left(\mu \mathrm{mol}(\mathrm{g} \mathrm{ww})^{-1} \mathrm{~m}^{-2} \mathrm{~d}^{-1}\right)\end{array}$ & References \\
\hline N. diversicolor & $79 \pm 24$ & $\begin{array}{l}\text { Banta et al., 1999; Kristensen } \\
\text { and Hansen, 1999; } \\
\text { Christensen et al., 2000; } \\
\text { Papaspyrou et al., 2010; } \\
\text { Kristensen et al., } 2011\end{array}$ \\
\hline A. marina & $331 \pm 122 *$ & $\begin{array}{l}\text { Banta et al., 1999; } \\
\text { Papaspyrou et al., } 2007\end{array}$ \\
\hline M. viridis & $345 \pm 219$ & $\begin{array}{l}\text { Karlson et al., 2005; } \\
\text { Kristensen et al., 2011; } \\
\text { Quintana et al., } 2013\end{array}$ \\
\hline
\end{tabular}

\begin{tabular}{|c|c|c|}
\hline \multicolumn{3}{|c|}{$\begin{array}{l}\mathrm{CO}_{2} \text { flux enhancement } \\
\left(\mu \mathrm{mol}(\mathrm{g} \mathrm{ww})^{-1} \mathrm{~m}^{-2} \mathrm{~d}^{-1}\right)\end{array}$} \\
\hline N. diversicolor & $102 \pm 21$ & $\begin{array}{l}\text { Hansen and Kristensen, } \\
\text { 1998; Banta et al., 1999; } \\
\text { Kristensen and Hansen, } \\
\text { 1999; Papaspyrou et al., 2010; } \\
\text { Kristensen et al., } 2011\end{array}$ \\
\hline A. marina & $412 \pm 18$ & $\begin{array}{l}\text { Banta et al., 1999; } \\
\text { Papaspyrou et al., 2007; Na } \\
\text { et al., } 2008\end{array}$ \\
\hline M. viridis & $420 \pm 148 *$ & $\begin{array}{l}\text { Kristensen et al., 2011; } \\
\text { Quintana et al., } 2013\end{array}$ \\
\hline
\end{tabular}

\begin{tabular}{|c|c|c|}
\hline \multicolumn{3}{|c|}{$\begin{array}{l}\mathrm{NH}_{4}^{+} \text {flux enhancement } \\
\left(\mu \mathrm{mol}(\mathrm{g} \mathrm{ww})^{-1} \mathrm{~m}^{-2} \mathrm{~d}^{-1}\right)\end{array}$} \\
\hline N. diversicolor & $15.1 \pm 4.1$ & $\begin{array}{l}\text { Hansen and Kristensen, 1998; } \\
\text { Kristensen and Hansen, } \\
\text { 1999; Christensen et al., } \\
\text { 2000; Papaspyrou et al., } \\
\text { 2010; Kristensen et al., } 2011\end{array}$ \\
\hline A. marina & $44.1 \pm 8.7^{*}$ & $\begin{array}{l}\text { Papaspyrou et al., 2007; Na } \\
\text { et al., } 2008\end{array}$ \\
\hline M. viridis & $84.5 \pm 42.3$ & $\begin{array}{l}\text { Karlson et al., 2005; } \\
\text { Viitasalo-Frösén et al., 2009; } \\
\text { Kristensen et al., 2011; } \\
\text { Quintana et al., } 2013\end{array}$ \\
\hline
\end{tabular}

\begin{tabular}{|c|c|c|}
\hline \multicolumn{3}{|c|}{$\begin{array}{l}\mathrm{NO}_{3}^{-} \text {flux enhancement } \\
\left(\mu \mathrm{mol}(\mathrm{g} \mathrm{ww})^{-1} \mathrm{~m}^{-2} \mathrm{~d}^{-1}\right)\end{array}$} \\
\hline N. diversicolor & $-2.3 \pm 1.0$ & $\begin{array}{l}\text { Hansen and Kristensen, } \\
\text { 1998; Christensen et al., } \\
\text { 2000; Kristensen et al., } 2011\end{array}$ \\
\hline A. marina & $-1.8 \pm 0.6^{*}$ & $\begin{array}{l}\text { Papaspyrou et al., 2007; Na } \\
\text { et al., } 2008\end{array}$ \\
\hline M. viridis & $-10.1 \pm 5.3$ & $\begin{array}{l}\text { Karlson et al., 2005; } \\
\text { Viitasalo-Frösén et al., 2009; } \\
\text { Kristensen et al., } 2011\end{array}$ \\
\hline
\end{tabular}

All results are obtained from laboratory incubations at $15^{\circ} \mathrm{C}$. Values are given as mean $\pm S E(n=3-5)$ or ${ }^{*} \pm$ range $(n=2)$. 
for $N$. diversicolor and comparable to that of A. marina, despite the much slower ventilation. The mechanisms behind the flux enhancement of $M$. viridis are different from those of the other two species (Kristensen et al., 2011; Quintana et al., 2013). The ventilation is too slow to maintain oxic conditions within and around the deeper parts of the burrow (Jovanovic et al., 2014). The surrounding sediment is instead supplied with reactive DOC excreted by the worms and sulfate from the overlying water, which feeds and stimulates sulfate reduction (Kristensen et al., 2011; Quintana et al., 2013). The produced $\mathrm{CO}_{2}$ is together with $\mathrm{H}_{2} \mathrm{~S}$ advectively driven to the sediment surface by bioirrigation, where $\mathrm{CO}_{2}$ is released to the overlying water and $\mathrm{H}_{2} \mathrm{~S}$ is oxidized under the consumption of $\mathrm{O}_{2}$.

Dissolved inorganic nitrogen (DIN) reactions and fluxes are also altered in the presence of the three polychaetes (Hansen and Kristensen, 1998; Papaspyrou et al., 2007; Kristensen et al., 2011). Mineralization of organic nitrogen to $\mathrm{NH}_{4}^{+}$is strongly coupled with carbon oxidation in a proportion dictated by the stoichiometry of degrading organic matter (Valdemarsen and Kristensen, 2010). The potential enhancement of $\mathrm{NH}_{4}^{+}$efflux by the three polychaetes is therefore proportional to that of $\mathrm{CO}_{2}$ efflux. Thus, the $\mathrm{CO}_{2}: \mathrm{NH}_{4}^{+}$ratios of the literature-based flux enhancements given in Table 4 are quite similar for $N$. diversicolor, A. marina and $M$. viridis, i.e., $6.8,9.3$, and 5.0, respectively.

The $\mathrm{NO}_{3}^{-}$flux, on the other hand, is very dependent on the balance between nitrification and denitrification and thus redox conditions in the sediment as well as the $\mathrm{NO}_{3}^{-}$concentration in the overlying water (Kessler et al., 2012; Evrard et al., 2013). The rapid flushing of open-ended burrows by $N$. diversicolor promotes oxic conditions and leads to nitrification in a narrow zone along the burrow. However, the steep gradients allow simultaneous rapid diffusion of the produced $\mathrm{NO}_{3}^{-}$together with $\mathrm{NO}_{3}^{-}$ventilated from the overlying water into anoxic sediment, where denitrification occurs (Nielsen et al., 2004; Nizzoli et al., 2007; Stief, 2013). Thus, the stimulated weight- and area-specific $\mathrm{NO}_{3}^{-}$flux from published literature provides an average net rate of $-2.3 \mu \mathrm{mol}(\mathrm{g} \mathrm{ww})^{-1} \mathrm{~m}^{-2} \mathrm{~d}^{-1}$ (Table 4). The intense upward advection of water through the feeding funnel in A. marina burrows eliminates any diffusion control and the associated rapid oxic-anoxic oscillations provide excellent conditions for coupled nitrification-denitrification ( $\mathrm{Na}$ et al., 2008). The average stimulated weight- and area-specific net $\mathrm{NO}_{3}^{-}$flux of $-1.8 \mu \mathrm{mol}(\mathrm{g}$ $\mathrm{ww})^{-1} \mathrm{~m}^{-2} \mathrm{~d}^{-1}$ (Table 4) reported in the literature therefore reflects to a large extent only denitrification of $\mathrm{NO}_{3}^{-}$from the overlying water. Enhanced uptake of $\mathrm{NO}_{3}^{-}$in $M$. viridis burrows has been observed frequently (e.g., Viitasalo-Frösén et al., 2009; Kristensen et al., 2011). Denitrification is for this species not coupled to nitrification (Kristensen et al., 2011; Bonaglia et al., 2013), but rather by efficient denitrification of $\mathrm{NO}_{3}^{-}$ventilated from the overlying water into the anoxic burrow environment (Jovanovic et al., 2014). Accordingly, the literature-based stimulated weight- and area-specific consumption of $\mathrm{NO}_{3}^{-}$in the presence of $M$. viridis is on average $-10.1 \mu \mathrm{mol}(\mathrm{g} \mathrm{ww})^{-1} \mathrm{~m}^{-2}$ $\mathrm{d}^{-1}$ (Table 4). The bioturbation driven stimulation of $\mathrm{NO}_{3}^{-}$fluxes are quite uncertain because of the strong dependence on overlying water concentration, which for the studies reported here varies from 4 to $40 \mu \mathrm{M}$. It is fortunate for the present ecosystem scale budgeting purposes, however, that the stimulated $\mathrm{NH}_{4}^{+}$fluxes exceed the more uncertain estimates for $\mathrm{NO}_{3}^{-}$by a factor of about ten.

\section{ECOSYSTEM SCALE BIOGEOCHEMICAL RESPONSE TO FAUNAL COMMUNITY SHIFTS}

The ecosystem scale impact of changes in dominance of the three examined polychaete species on sediment biogeochemistry (i.e., metabolism and nutrient fluxes) in the inner Odense Fjord can readily be estimated from their functional traits, i.e., the weightand area-specific enhancements presented above. The predictions are limited to the growth season (May-October) where the average water temperature is $\sim 15^{\circ} \mathrm{C}$ as in the source experiments. However, before evaluating the relative flux enhancement, the level of basic heterotrophic metabolism and nutrient fluxes in sediment devoid of fauna must be established. These are here derived from station OF123 using unpublished results ${ }^{1}$ measured every year over the last 10 years on darkened intact sediment cores at $15^{\circ} \mathrm{C}$ in August. The heterotrophic fluxes (in $\mathrm{mmol} \mathrm{m} \mathrm{m}^{-2} \mathrm{~d}^{-1}$ ) corrected for faunal contribution were, $\mathrm{O}_{2}: 66.5 \pm 21.3 ; \mathrm{CO}_{2}$ : $76.8 \pm 13.1 ; \mathrm{NH}_{4}^{+}: 2.2 \pm 2.3$; and $\mathrm{NO}_{3}^{-}: 0.22 \pm 1.6$. These are within the range found for undisturbed and defaunated sediment cores from various locations in Odense Fjord (Valdemarsen et al., 2014).

Before the major shift in faunal abundance occurred in 2004, the estimated total enhancement of benthic metabolism $\left(\mathrm{O}_{2}\right.$ and $\mathrm{CO}_{2}$ flux) by $N$. diversicolor and $A$. marina was rather small (Figures 7A,B), equivalent to $16-30 \%$ increase relative to the basic rates. The major contributor during this period was A. marina, accounting for $62-71 \%$ of the total enhancement. A similar low faunal contribution is normally observed in undisturbed systems close to steady state with respect to organic input and faunal abundance (Kristensen, 2000). During the transient period of $A$. marina and $M$. viridis expansion in 2004-2006, the enhancement of $\mathrm{O}_{2}$ and $\mathrm{CO}_{2}$ flux relative to the basic rate increased to $43-61 \%$, with A. marina, M. viridis and $N$. diversicolor being responsible for about 80,10 , and $10 \%$, respectively. The key organism affecting benthic metabolism was therefore always $A$. marina due to its large biomass and efficient enhancement of microbial reactions. A similar stronger impact of $A$. marina than $N$. diversicolor has been observed previously (Banta et al., 1999).

Faunal enhancement of $\mathrm{NH}_{4}^{+}$fluxes (Figure 7C) showed the same pronounced effect during the A. marina and $M$. viridis expansion period as observed for benthic metabolism, but were much stronger relative to the basic rate. Even during the preexpansion period, the enhancement of $\mathrm{NH}_{4}^{+}$fluxes reached 75-127\%. A. marina was also here more important than $N$. diversicolor, but to a slightly lesser extent, 57-68\%. During the crucial expansion years of 2004-2006, the $\mathrm{NH}_{4}^{+}$flux enhancement roughly doubled to $192-244 \%$, causing a substantial release of DIN to the overlying water. Hansen and Kristensen (1997) observed a similar 2-4 times increase in $\mathrm{NH}_{4}^{+}$flux after

\footnotetext{
${ }^{1}$ Measurements were done by students during the $\mathrm{PhD}$ course, Aquatic Microbial and Molecular Ecology, held annually at University of Southern Denmark
} 

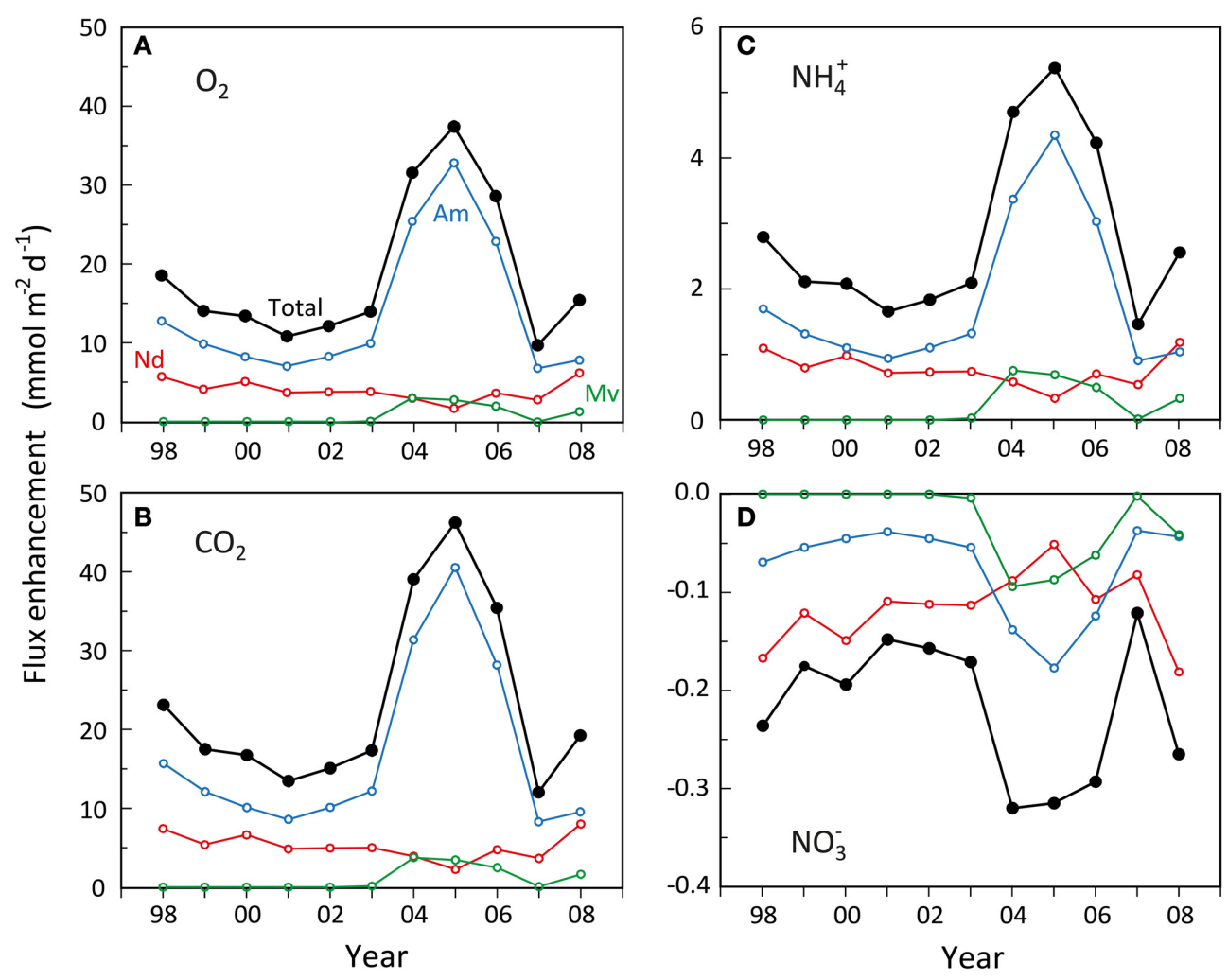

FIGURE 7 | Estimated development in enhancement of (A) benthic $\mathrm{O}_{2}$ uptake, (B) benthic $\mathrm{CO}_{2}$ release, (C) benthic $\mathrm{NH}_{4}^{+}$release and (D) benthic $\mathrm{NO}_{3}^{-}$uptake during summer $\left(15^{\circ} \mathrm{C}\right)$ caused by Nereis diversicolor $(\mathrm{Nd})$, Arenicola marina (Am) and Marenzelleria viridis (Mv) populations in the

inner Odense Fjord from 1998 to 2008. The black lines indicate the total. Data were obtained from the average biomass at the 4 stations shown in Figure 5 multiplied with the literature-based weight-, area-, and time-specific conversion factors of $\mathrm{O}_{2}, \mathrm{CO}_{2}, \mathrm{NH}_{4}^{+}$, and $\mathrm{NO}_{3}^{-}$flux enhancement as shown in Table 4.

introduction of excess fauna to undisturbed sediment cores. The partitioning of the enhancement among the three polychaetes species was almost identical to that observed for $\mathrm{O}_{2}$ and $\mathrm{CO}_{2}$ fluxes, i.e., about 80,10 , and $10 \%$ for A. marina, M. viridis, and $N$. diversicolor, respectively. This is an obvious reflection of the aforementioned similarity in $\mathrm{CO}_{2}: \mathrm{NH}_{4}^{+}$ratios of solute flux enhancement by the three species.

The faunal induced enhancement of $\mathrm{NO}_{3}^{-}$fluxes into the sediment, on the other hand, was low in absolute terms, but within the same order of magnitude as the basic efflux without fauna (i.e., $0.22 \pm 1.6 \mathrm{mmol} \mathrm{m}^{-2} \mathrm{~d}^{-1}$ ). Accordingly, all three polychaete species apparently stimulated denitrification more than nitrification causing a balanced (i.e., close to zero) total community net exchange of $\mathrm{NO}_{3}^{-}$at all times. The enhanced influx of $\mathrm{NO}_{3}^{-}$was only marginally higher during the expansion years than in the pre-expansion period (i.e., -0.29 to -0.32 compared with -0.15 to $-0.24 \mathrm{mmol} \mathrm{m}^{-2} \mathrm{~d}^{-1}$ ) (Figure 7D). N. diversicolor was the most important contributor during the pre-expansion period, accounting for $70-80 \%$ of the total enhancement. This diminished to $16-37 \%$ during the expansion, where A. marina contributed with $42-56 \%$ and $M$. viridis with $21-29 \%$. Thus, the role of A. marina on $\mathrm{NO}_{3}^{-}$influx was lower than for the other solutes and this species was only more important than the other two during the expansion years.

\section{IMPACTS OF COMMUNITY SHIFTS AND FUNCTIONAL TRAITS OF BENTHIC FAUNA ON BENTHIC-PELAGIC COUPLING AND ECOSYSTEM FUNCTIONING}

It is obvious from the present study that dramatic shifts in benthic fauna composition and functional traits, as exemplified by the temporal expansion of $A$. marina and $M$. viridis and decline of $N$. diversicolor, affect benthic-pelagic coupling and thus the functioning of the entire inner Odense Fjord. The historical records of summer nutrient levels in the water column of this area (Figure 2) for the time period corresponding to the fauna surveys presented here (1998-2008) provide a conspicuous pattern with strongly elevated concentrations of DIN exactly during the years (20042006) where A. marina and M. viridis populations expanded. Previous studies have also reported altered sediment biogeochemistry in response to benthic community shifts (Thrush et al., 2006; Lohrer et al., 2010; Kristensen et al., 2011; Norkko et al., 2013), but only few have assessed how these changes subsequently affect the benthic-pelagic coupling and cause changes in the functioning of entire ecosystems (e.g., Lohrer et al., 2004). The correlation between faunal DIN flux enhancement and summer DIN levels in the water column observed in this study was highly significant $(p<0.001)$ with a correlation coefficient $\left(r^{2}\right)$ of 0.900 . Although no direct causal relationship has been proved, we are confident that the faunal induced excess $\mathrm{NH}_{4}^{+}$delivered from the benthic 
system during this period enriched the shallow overlying water column of the inner Odense Fjord in DIN. The increased summer $\mathrm{NO}_{3}^{-}$levels during the expansion years do not comply with the fauna stimulated $\mathrm{NO}_{3}^{-}$uptake, and were probably caused by excessive nitrification of $\mathrm{NH}_{4}^{+}$released into the oxic water column.

Daily fauna stimulation of benthic DIN efflux during the years with a shift dominating functional traits (i.e., expansion of A. marina) potentially increased summer DIN concentrations by $3.38 \mu \mathrm{M}$ in the $0.8 \mathrm{~m}$ deep water column (Figure 8). However, when the average water residence time of 23 days and $26 \%$ denitrification of delivered DIN (Petersen et al., 2009) are considered, 0.14 and $0.88 \mu \mathrm{M}$, respectively, of the faunal contribution is removed daily. The remaining average $2.36 \mu \mathrm{M} / \mathrm{d}$ excess DIN in most likely stimulated phytoplankton production and counteracted DIN limitation during the critical phase in summer with replete DIP levels. However, to maintain the measured elevated DIN concentration of $2.53 \mu \mathrm{M}$, the excess consumption of DIN by phytoplankton should on average not exceed $2.36 \mu \mathrm{M} \mathrm{d}^{-1}$, which corresponds well with reported values of up to $2.4 \mu \mathrm{M} \mathrm{d}^{-1}$ (Fyns Amt, 2004). Accordingly, water column Chlorophyll a, as a proxy for phytoplankton biomass, showed increased levels exactly during the A. marina and M. viridis expansion period (Figure 3). The correlation between summer DIN levels and Chlorophyll a in the water column was highly significant $(p<0.001)$ with a correlation coefficient $\left(r^{2}\right)$ of 0.833 . A dark horse in this calculation is the dual functional traits of $N$. diversicolor, i.e., its capacity to simultaneously stimulate release of nutrients to the overlying water (e.g., Kristensen and Hansen, 1999) and graze on phytoplankton by suspension feeding (Riisgård, 1991; Christensen et al., 2000). It is possible that part of the increased phytoplankton concentration from 2004 to 2006 is coupled to the diminished population size, and thus less intense suspension feeding by $N$. diversicolor during this period, but the exact quantitative role of this is currently unknown. In any case, the present observations are to our knowledge the first in situ proof of how benthic infauna community shifts promote new functional traits, which causes altered benthic-pelagic coupling and modifies overlying nutrient levels and phytoplankton biomass in coastal marine systems. This suggests that benthic infauna community shifts significantly influence ecosystem functioning.

\section{CONCLUSIONS AND PERSPECTIVES}

Our study support the contention of Thrush et al. (2006) that shifts in large infaunal abundance driven by anthropogenic and natural disturbances may lead to functional changes and cause dramatic changes in the structure and performance of ecosystems. Shifts in benthic fauna communities (e.g., regime shifts), as exemplified from our Odense Fjord case study, clearly involve all three key features affecting ecosystem functioning, i.e., species composition, species functional traits and species impact on biogeochemical cycling. These features must therefore be considered in concert and not individually because any shift in e.g., species dominance is tightly coupled to interactions among the functional traits of involved species and thus their specific impact on sediment biogeochemistry. The dynamics between the three features during a benthic community shift ultimately

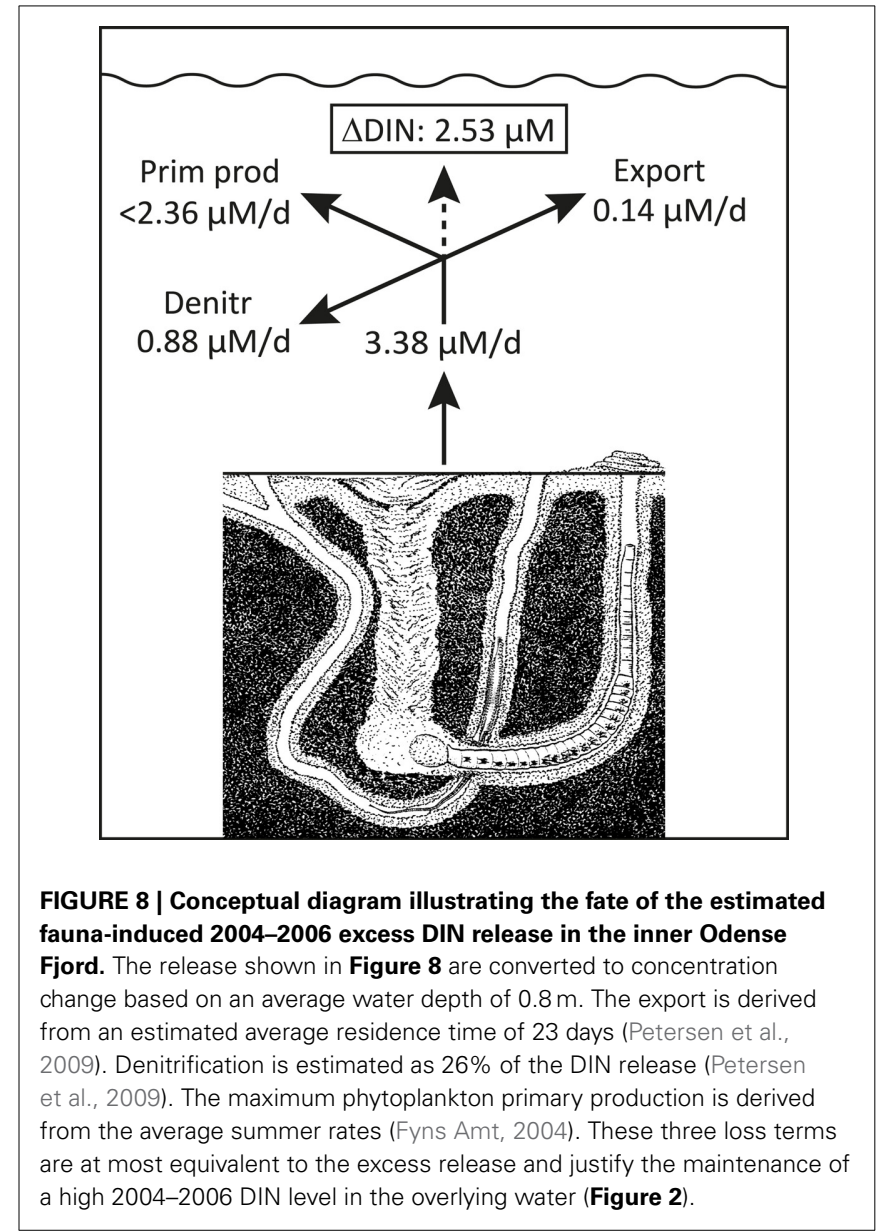

affect benthic organic matter mineralization and nutrient cycles. This leads to altered benthic-pelagic coupling and thus nutrient availability for primary producers, which consequently modifies the overall ecosystem functioning (Grall and Chauvaud, 2002). We therefore have strong evidence to support our first hypothesis. Such modifications in pelagic foodweb dynamics driven be altered benthic-pelagic coupling may conversely cause feedback to the benthic system in the form of altered deposition of organic material - and thus provide food for the benthic fauna and associated microbial communities. These important feedbacks between large macrofauna, biogeochemical processes, and ecosystem productivity clearly manifest our second hypothesis.

The focus in our study is mostly directed toward the role of fauna community shift and functional traits for the exchange of nutrients across the sediment-water interface. This is an obvious consequence of the dominant functional traits involved, as the investigated large species all enhanced the nutrient release to the overlying water. As found by Norkko et al. (2013), the largest species, A. marina, had the strongest impact on nutrient fluxes. However, suspension-feeding by $N$. diversicolor could potentially reverse the benthic-pelagic coupling and cause enhanced deposition of particles and create a clear water state (Riisgård, 1991). This is exactly what was observed by Petersen et al. (2008) in Ringkøbing Fjord where the shift in dominance to one suspension feeding bivalve, Mya arenaria, cleared all phytoplankton from the 
water column. This substantiates the importance for identifying the functional traits of the species involved in a community shift before investigating its consequences for benthic-pelagic coupling and ecosystem functioning.

Although we believe that shifts in benthic community structure affect the functioning of most marine ecosystems, the depth and hydrodynamics of the overlying water column are crucial for the actual ecosystem-scale expression of the altered benthicpelagic coupling (Rasmussen and Josefson, 2002; Mauna et al., 2011). For example, nutrients delivered from the benthos may in estuaries with an $8 \mathrm{~m}$ deep water column be diluted by up to 100 times compared with the Odense Fjord case study. The exact response of course depends on the water residence time of each individual estuary (Rasmussen and Josefson, 2002). Thus, when regime shifts occur in deep or regularly flushed estuaries, the associated chemical changes may not be measurable with standard analytical techniques. Moreover, the growth response of phytoplankton to few nM changes in nutrient levels will according to standard growth kinetics obviously be very limited (Ballantyne et al., 2008; Teixeira et al., 2014). Furthermore, the recycling of nutrients in deep-water environments occurs to a large extent in the water column, leaving less deposited organic material for benthic organisms (Suess, 1980; Hedges and Keil, 1995). Consequently, the benthic fauna abundance and biomass are lower and biogeochemical cycling slower, diminishing the impact of any community shift on benthic-pelagic coupling and ecosystem functioning. We emphasize that our findings in principle should be valid for all marine areas, but that they are primarily expressed in shallow (i.e., few meter or less deep) estuaries, and should not directly be extrapolated to deeper coastal environments. We therefore recommend that the complex linkages and interactions related to benthic community shifts and benthicpelagic coupling are first studied in shallow environments to obtain sufficient knowledge about the drivers and controls before exploring these issues in deep-water environments.

\section{ACKNOWLEDGMENTS}

We thank all colleagues, students, and technicians who have contributed with essential background data for this study. This paper strongly depends on and could not have been written without their efforts over the years. The work was funded by the Brazilian National Research Council (CNPq) (individual post-doctoral grant \# 201912/2008-2 to Cintia O. Quintana), by the Danish Council for Independent Research (contract \# 09-071369 and 12-127012 to Erik Kristensen, Mogens R. Flindt, and Matthieu Delefosse), by the Danish Council for Strategic Research (contract \# 09-063190 and 12-132701 to Erik Kristensen, Mogens R. Flindt, and Thomas Valdemarsen), and Aage V. Jensen Nature Foundation (contract \#120925 to Erik Kristensen, Mogens R. Flindt, and Thomas Valdemarsen).

\section{REFERENCES}

Aller, R. C. (1994). Bioturbation and remineralization of sedimentary organic matter: effects of redox oscillation. Chem. Geol. 114, 331-345. doi: 10.1016/00092541(94)90062-0

Ballantyne, F., Menge, D. N. L., Ostling, A., and Hosseini, P. (2008). Nutrient recycling affects autotroph and ecosystem stoichiometry. Am. Nat. 171, 511-523. doi: $10.1086 / 528967$
Banta, G. T., Holmer, M., Jensen, M. H., and Kristensen, E. (1999). Effects of two polychaete worms, Nereis diversicolor and Arenicola marina, on aerobic and anaerobic decomposition in sandy marine sediment. Aquat. Microb. Ecol. 19, 189-204. doi: 10.3354/ame019189

Beaugrand, G. (2004). The North Sea regime shift: evidence, causes, mechanisms and consequences. Prog. Oceanogr. 60, 245-262. doi: 10.1016/j.pocean.2004. 02.018

Bertics, V., and Ziebis, W. (2010). Bioturbation and the role of microniches for sulfate reduction in coastal marine sediments. Environ. Microbiol. 12, 3022-3034. doi: 10.1111/j.1462-2920.2010.02279.x

Beukema, J. J., and De Vlas, J. (1979). Population parameters of the lugworm Arenicola marina, lving on tidal flats in the Dutch Wadden Sea. Neth. J. Sea Res. 13, 331-353. doi: 10.1016/0077-7579(79)90010-3

Blank, M., Laine, A. O., Jürss, K., and Bastrop, R. (2008). Molecular identification key based on PCR/RFLP for three polychaete sibling species of the genus Marenzelleria, and the species' current distribution in the Baltic Sea. Helgol. Mar. Res. 62,129-141. doi: 10.1007/s10152-007-0081-8

Boero, F. (1999). "Community ecology: a life cycle perspective," in Perspectives in Ecology, ed A. Farina (Leiden: Backyus Publishers), 335-342.

Boero, F., and Bonsdorff, E. (2007). A conceptual framework for marine biodiversity and ecosystem functioning. Mar. Ecol. 28, 134-145. doi: 10.1111/j.14390485.2007.00171.x

Bonaglia, S., Bartoli, M., Gunnarsson, J. S., Rahm, L., Raymond, C., Svensson, O., et al. (2013). Effect of reoxygenation and Marenzelleria spp. bioturbation on Baltic Sea sediment metabolism. Mar. Ecol. Prog. Ser. 482, 43-55. doi: 10.3354/meps 10232

Bonsdorff, E., Norkko, A., and Boström, C. (1995). "Recruitment and population maintenance of the bivalve Macoma balthica (L.) - factors affecting settling success and early survival on shallow sandy bottoms," in Biology and Ecology of Shallow Coastal Waters. Proceedings of the 28th EMBS, 1993, eds A. Eleftheriou, A. D. Ansell, and C. J. Smith (Fredensborg: Olsen \& Olsen), 253-260.

Brady, D. C., Testa, J. M., Di Toro, D. M., Boynton, W. R., and Kemp, W. M. (2013). Sediment flux modeling: calibration and application for coastal systems. Estuar. Coast. Shelf Sci. 117, 107-124. doi: 10.1016/j.ecss.2012.11.003

Braeckman, U., Provoost, P., Gribsholt, B., Van Gansbeke, D., Middelburg, J. J., Soetaert, K., et al. (2010). Role of macrofauna functional traits and density in biogeochemical fluxes and bioturbation. Mar. Ecol. Prog. Ser. 399, 173-186. doi: 10.3354/meps08336

Brigolin, D., Lovato, T., Rubino, A., and Pastres, R. (2011). Coupling earlydiagenesis and pelagic biogeochemical models for estimating the seasonal variability of $\mathrm{N}$ and $\mathrm{P}$ fluxes at the sediment-water interface: application to the northwestern Adriatic coastal zone. J. Mar. Syst. 87, 239-255. doi: 10.1016/j.jmarsys.2011.04.006

Bulling, M. T., White, P. C. L., Raffaelli, D., and Pierce, G. J. (2006). Using model systems to address the biodiversity-ecosystem functioning process. Mar. Ecol. Prog. Ser. 311, 295-309. doi: 10.3354/meps311295

Christensen, B., Vedel, A., and Kristensen, E. (2000). Carbon and nitrogen fluxes in sediment inhabited by suspension-feeding (Nereis diversicolor) and non-suspension-feeding (Nereis virens) polychaetes. Mar. Ecol. Prog. Ser. 192,203-217. doi: 10.3354/meps192203

Crowe, T. P., Cusson, M., Bulleri, F., Davoult, D., Arenas, F., Aspden, R., et al. (2013). Large-scale variation in combined impacts of canopy loss and disturbance on community structure and ecosystem functioning. PLoS ONE 8:e66238. doi: 10.1371/journal.pone.0066238

Delefosse, M., Banta, G. T., Canal-Vergés, P., Penha-Lopes, G., Quintana, C. O., Valdemarsen, T., et al. (2012). Macrobenthic community response to the Marenzelleria viridis (Polychaeta) invasion of a Danish estuary. Mar. Ecol. Prog. Ser. 461, 83-94. doi: 10.3354/meps09821

Delefosse, M., and Kristensen, E. (2012). Burial of Zostera marina seeds in sediment inhabited by three polychaetes: laboratory and field studies. J. Sea Res. 71, 41-49. doi: 10.1016/j.seares.2012.04.006

Doering, P. H. (1989). On the contribution of the benthos to pelagic production. J. Mar. Res. 47, 371-383. doi: 10.1357/002224089785076253

Dornhoffer, T., Waldbusser, G. G., and Meile, C. (2012). Burrow patchiness and oxygen fluxes in bioirrigated sediments. J. Exp. Mar. Biol. Ecol. 412, 81-86. doi: 10.1016/j.jembe.2011.11.004

Eriksson, B. K., van der Heide, T., van de Koppel, J., Piersma, T., van der Veer, H. W., and Olff, H. (2010). Major changes in the ecology of the Wadden Sea: 
human impacts, ecosystem engineering and sediment dynamics. Ecosystems 13, 752-764. doi: 10.1007/s10021-010-9352-3

Essink, K. (1999). Dispersal and development of Marenzelleria spp. (Polychaeta, Spionidae) populations in NW Europe and The Netherlands. Helgol. Meeresunters. 52, 367-372. doi: 10.1007/BF02908910

Evrard, V., Glud, R. N., and Cook, P. L. M. (2013). The kinetics of denitrification in permeable sediments. Biogeochemistry 113, 563-572. doi: 10.1007/s10533-0129789-x

Flach, E. C. (1992). The influence of four macrozoobenthic species on the abundance of the amphipod Corophium volutator on tidal flats of the Wadden Sea. Neth. J. Sea Res. 29, 379-394. doi: 10.1016/0077-7579(92)90077-R

Fyns Amt. (1997). Vandmiljøovervågning - Kystvande 1996. Odense: Fyns Amt.

Fyns Amt. (2004). Vandmiljøovervågning - Kystvande 2003. Odense: Fyns Amt.

Grall, J., and Chauvaud, L. (2002). Marine eutrophication and benthos: the need for new approaches and concepts. Glob. Change Biol. 8, 813-830. doi: 10.1046/j.1365-2486.2002.00519.x

Grenz, C., Cloern, J. E., Hager, S. W., and Cole, B. E. (2000). Dynamics of nutrient cycling and related benthic nutrient and oxygen fluxes during a spring phytoplankton bloom in South San Francisco Bay (USA). Mar. Ecol. Prog. Ser. 197, 67-80. doi: 10.3354/meps197067

Greve, T. M., Krause-Jensen, D., Rasmussen, M. B., and Christensen, P. B. (2005). Means of rapid eelgrass (Zostera marina L.) recolonization in former dieback areas. Aquat. Bot. 82, 143-156. doi: 10.1016/j.aquabot.2005.03.004

Hansen, K., and Kristensen, E. (1997). Impact of macrofaunal recolonization on benthic metabolism and nutrient fluxes in a shallow marine sediment previously overgrown with macroalgal mats. Estuar. Coast. Shelf Sci. 45, 613-628. doi: $10.1006 /$ ecss. 1996.0229

Hansen, K., and Kristensen, E. (1998). The impact of the polychaete Nereis diversicolor and enrichment with macroalgal (Chaetomorpha linum) detritus on benthic metabolism and nutrient dynamics in organic-poor and organicrich sediment. J. Exp. Mar. Biol. Ecol. 231, 201-223. doi: 10.1016/S00220981(98)00070-7

Hare, S. R., and Mantua, N. J. (2000). Emperical evidence for North Pacific regime shifts in 1977 and 1989. Prog. Oceanogr. 47,103-145. doi: 10.1016/S00796611(00)00033-1

Hauxwell, J., Cebrián, J., Furlong, C., and Valiela, I. (2001). Macroalgal canopies contribute to eelgrass (Zostera marina) decline in temperate estuarine ecosystems. Ecology 82, 1007-1022. doi: 10.1890/00129658(2001)082 [1007:MCCTEZ]2.0.CO;2

Hedges, J. I., and Keil, R. G. (1995). Sedimentary organic matter preservation: an assessment and speculative synthesis. Mar. Chem. 49, 81-115. doi: 10.1016/0304-4203(95)00008-F

Hochard, S., Pinazoa, C., Rochelle-Newall, E., and Pringault, O. (2012). Benthic pelagic coupling in a shallow oligotrophic ecosystem: importance of microphytobenthos and physical forcing. Ecol. Model. 247, 307-318. doi: 10.1016/j.ecolmodel.2012.07.038

Hooper, D. U., Chapin, F. S., Ewel, J. J., Hector, A., Inchausti, P., Lavorel, S., et al. (2005). Effects of biodiversity on ecosystem functioning: a consensus of current knowledge. Ecol. Monogr. 75, 3-35. doi: 10.1890/04-0922

Hulthe, G., Hulth, S., and Hall, P. O. J. (1998). Effect of oxygen on degradation rate of refractory and labile organic matter in continental margin sediments. Geochim. Cosmochim. Acta 62, 1319-1328. doi: 10.1016/S0016-7037(98) 00044-1

Ieno, E. N., Solan, M., Batty, P., and Pierce, G. J. (2006). How biodiversity affects ecosystem functioning: roles of infaunal species richness, identity and density in the marine benthos. Mar. Ecol. Prog. Ser. 311, 263-271. doi: 10.3354/meps311263

Jovanovic, Z., Larsen, M., Quintana, C. O., Kristensen, E., and Glud, R. N. (2014). Oxygen dynamics and porewater transport in sediments inhabited by the invasive polychaete Marenzelleria viridis. Mar. Ecol. Prog. Ser. 504, 181-192. doi: $10.3354 /$ meps 10737

Karlson, K., Hulth, S., Ringdahl, K., and Rosenberg, R. (2005). Experimental recolonisation of Baltic Sea reduced sediments: survival of benthic macrofauna and effects on nutrient cycling. Mar. Ecol. Prog. Ser. 294, 35-49. doi: 10.3354/meps294035

Kessler, A. J., Glud, R. N., Cardenas, M. B., Larsen, M., Bourke, M. F., and Cook, P. L. M. (2012). Quantifying denitrification in rippled permeable sands through combined flume experiments and modeling. Limnol. Oceanogr. 57, 1217-1232. doi: $10.4319 /$ lo.2012.57.4.1217
Koed, A., Rasmussen, G., and Rasmussen, E. B. (1997). Havørredbestandene $i$ Odense Å og Stavids A Systemerne i Relation til Fynsvarket. DFU-Report 29-97, Frederiksberg: DSR Print.

Kotta, J., Kotta, I., Simm, M., Lankov, A., Lauringson, V., Põllumäe, A., et al. (2006). Ecological consequences of biological invasions: three invertebrate case studies in the north-eastern Baltic Sea. Helgol. Mar. Res. 60, 106-112. doi: 10.1007/s10152-006-0027-6

Kristensen, E. (2000). Organic matter diagenesis at the oxic/anoxic interface in coastal marine sediments, with emphasis on the role of burrowing animals. Hydrobiologia 426, 1-24. doi: 10.1023/A:1003980226194

Kristensen, E. (2001). Impact of polychaetes (Nereis spp. and Arenicola marina) on carbon biogeochemistry in coastal marine sediment. Geochem. Trans. 2, 92-104. doi: 10.1186/1467-4866-2-92

Kristensen, E., Delefosse, M., Quintana, C. O., Banta, G. T., Petersen, H. C., and Jørgensen, B. (2013). Distribution pattern of benthic invertebrates in Danish estuaries: the use of Taylor's power law as a species-specific indicator of dispersion and behavior. J. Sea Res. 77, 70-78. doi: 10.1016/j.seares.2012.10.003

Kristensen, E., and Hansen, K. (1999). Transport of carbon dioxide and ammonium in bioturbated (Nereis diversicolor) coastal, marine sediments. Biogeochemistry 45, 147-168. doi: 10.1007/BF01106779

Kristensen, E., Hansen, T., Delefosse, M., Banta, G. T., and Quintana, C. O. (2011). Contrasting effects of the polychaetes Marenzelleria viridis and Nereis diversicolor on benthic metabolism and solute transport in sandy coastal sediment. Mar. Ecol. Prog. Ser. 425, 125-139. doi: 10.3354/meps09007

Kristensen, E., and Holmer, M. (2001). Decomposition of plant materials in marine sediment exposed to different electron acceptors $\left(\mathrm{O}_{2}, \mathrm{NO}_{3}^{-}\right.$and $\left.\mathrm{SO}_{4}^{2-}\right)$, with emphasis on substrate origin, degradation kinetics and the role of bioturbation. Geochim. Cosmochim. Acta 65, 419-434. doi: 10.1016/S0016-7037(00)00532-9

Kristensen, E., Penha-Lopes, G., Delefosse, M., Valdemarsen, T., Quintana, C. O., and Banta, G. T. (2012). What is bioturbation? Need for a precise definition for fauna in aquatic sciences. Mar. Ecol. Prog. Ser. 446, 285-302. doi: 10.3354/meps09506

Kronvang, B., Andersen, H. E., Børgesen, C., Dalgaard, T., Larsen, S. E., Bøgestrand, J., et al. (2008). Effects of policy measures implemented in Denmark on nitrogen pollution of the aquatic environment. Environ. Sci. Policy 11, 144-152. doi: 10.1016/j.envsci.2007.10.007

Lindqvist, S., Gilbert, F., Eriksson, S. P., and Hulth, S. (2013). Activities by Hediste diversicolor under different light regimes: experimental quantification of particle reworking using time-resolved imaging. J. Exp. Mar. Biol. Ecol. 448, 240-249. doi: 10.1016/j.jembe.2013.06.014

Lohrer, A. M., Halliday, N. J., Thrush, S. F., Hewitt, J. E., and Rodil, I. F. (2010). Ecosystem functioning in a disturbance-recovery context: contribution of macrofauna to primary production and nutrient release on intertidal sandflats. J. Exp. Mar. Biol. Ecol. 390, 6-13. doi: 10.1016/j.jembe.2010.04.035

Lohrer, A. M., Thrush, S. F., and Gibbs, M. M. (2004). Bioturbators enhance ecosystem function through complex biogeochemical interactions. Nature 431, 1092-1095. doi: 10.1038/nature 03042

Mauna, A. C., Acha, E. M., Lasta, M. L., and Iribarne, O. O. (2011). The influence of a large SW Atlantic shelf-break frontal system on epibenthic community composition, trophic guilds, and diversity. J. Sea Res. 66, 39-46. doi: 10.1016/j.seares.2011.04.014

Na, T., Gribsholt, B., Galaktionov, O. S., Lee, T., and Meysman, F. J. R. (2008). Influence of advective bio-irrigation on carbon and nitrogen cycling in sandy sediments. J. Mar. Res. 66: 691-722. doi: 10.1357/002224008787536826

Nielsen, O. I., Gribsholt, B., Kristensen, E., and Revsbech, N. P. (2004). Microscale distribution of oxygen and nitrate in sediment inhabited by Nereis diversicolor; spatial patterns and estimated reaction rates. Aquat. Microb. Ecol. 34, 23-32. doi: 10.3354/ame 034023

Nizzoli, D., Bartoli, M., Cooper, M., Welsh, D. T., Underwood, G. J. C., and Viaroli, P. (2007). Implications for oxygen, nutrient fluxes and denitrification rates during the early stage of sediment colonisation by the polychaete Nereis spp. in four estuaries. Estuar. Coast. Shelf Sci. 75, 125-134. doi: 10.1016/j.ecss.2007.03.035

Norkko, A., Villnäs, A., Norkko, J., Valanko, S., and Pilditch, C. (2013). Size matters: implications of the loss of large individuals for ecosystem function. Sci. Rep. 3, 2646. doi: 10.1038/srep02646

Papaspyrou, S., Kristensen, E., and Christensen, B. (2007). Arenicola marina (Polychaeta) and organic matter mineralisation in sandy marine sediments; in situ and microcosm comparison. Estuar. Coast. Shelf Sci. 72, 213-222. doi: 10.1016/j.ecss.2006.10.020 
Papaspyrou, S., Thessalou-Legaki, M., and Kristensen, E. (2010). The influence of infaunal (Nereis diversicolor) abundance on degradation of organic matter in sandy sediments. J. Exp. Mar. Biol. Ecol. 393, 148-157. doi: 10.1016/j.jembe. 2010.07.015

Pérez-Ruzafa, A., Marcos, C., Pérez-Ruzafa, I. M., and Pérez-Marcos, M. (2011). Coastal lagoons: "transitional ecosystems" between transitional and coastal waters. J. Coast. Conserv. 15, 369-392. doi: 10.1007/s11852-010-0095-2

Petersen, J. D., Rask, N., Madsen, H. B., Jørgensen, O. T., Petersen, S. E., Nielsen, S. V. K., et al. (2009). Odense Pilot River Basin: implementation of the EU Water Framework Directive in a shallow eutrophic estuary (Odense Fjord, Denmark) and its upstream catchment. Hydrobiologia 629,71-89. doi: 10.1007/s10750009-9774-0

Petersen, J. K., Hansen, J. W., Laursen, M. B., Clausen, P., Carstensen, J., and Conley, D. J. (2008). Regime shift in a coastal marine ecosystem. Ecol. Appl. 18, 497-510. doi: 10.1890/07-0752.1

Pischedda, L., Cuny, P., Esteves, J. L., Poggiale, J.-C., and Gilbert, F. (2012). Spatial oxygen heterogeneity in a Hediste diversicolor irrigated burrow. Hydrobiologia 680, 109-124. doi: 10.1007/s10750-011-0907-x

Quintana, C. O., Hansen, T., Delefosse, M., Banta, G. T., and Kristensen, E. (2011). Burrow ventilation and associated porewater irrigation by the polychaete Marenzelleria viridis. J. Exp. Mar. Biol. Ecol. 397, 179-187. doi: 10.1016/j.jembe.2010.12.006

Quintana, C. O., Kristensen, E., and Valdemarsen, T. (2013). Impact of the invasive polychaete Marenzelleria viridis on the biogeochemistry of sandy marine sediments. Biogeochemistry 115, 95-109. doi: 10.1007/s10533-012-9820-2

Rasmussen, B., and Josefson, A. B. (2002). Consistent estimates for the residence time of micro-tidal estuaries. Estuar. Cost. Shelf Sci. 54, 65-73. doi: 10.1006/ecss.2001.0836

Reise, K., Olenin, S., and Thieltges, D. W. (2006). Are aliens threatening European aquatic coastal ecosystems? Helgol. Mar. Res. 60, 77-83. doi: 10.1007/s10152006-0024-9

Reitze, M., and Schöttler, U. (1989). The time dependence of adaptation to reduced salinity in the lugworm Arenicola marina L. (Annelida: Polychaeta). Comp. Biochem. Physiol. 93A, 549-559. doi: 10.1016/0300-9629(89)90009-1

Riisgård, H. U. (1991). Suspension feeding in the polychaete Nereis diversicolor. Mar. Ecol. Prog. Ser. 70, 29-37. doi: 10.3354/meps070029

Riisgård, H. U., and Banta, G. T. (1998). Irrigation and deposit feeding by the lugworm Arenicola marina, characteristics and secondary effects on the environment. A review of current knowledge. Vie Milieu 48, 243-257

Riisgård, H. U., Berntsen, I., and Tarp, B. (1996). The lugworm (Arenicola marina) pump: characteristics, modeling and energy cost. Mar. Ecol. Prog. Ser. 138, 149-156. doi: 10.3354/meps138149

Riisgård, H. U., Jensen, M. H., and Rask, N. (2008). "Odense fjord and kerteminde fjord/kertinge nor," in Ecology of Baltic Coastal Waters. Ecological Studies 197, ed U. Schiewer (Berlin: Springer), 361-394. doi: 10.1007/978-3-540-73524-3_16

Riisgård, H. U., and Larsen, P. S. (2005). Water pumping and analysis of flow in burrowing zoobenthos: an overview. Aquat. Ecol. 39, 237-258. doi: 10.1007/s10452004-1916-x

Scheffer, M., and Carpenter, S. R. (2003). Catastrophic shifts in ecosystems: linking theory and observation. Trends Ecol. Evol. 18, 648-656. doi: 10.1016/j.tree.2003.09.002

Shull, D. H., Benoit, J. M., Wojcik, C., and Senning, J. R. (2009). Infaunal burrow ventilation and pore-water transport in muddy sediments. Estuar. Coast. Shelf Sci. 83, 277-286. doi: 10.1016/j.ecss.2009.04.005

Shumway, S. A., and Davenport, J. (1977). Some aspects of the physiology of Arenicola marina (Polychaeta) exposed to fluctuating salinities. J. Mar. Biol. Ass. U.K. 57, 907-924. doi: 10.1017/S0025315400026011

Solan, M., Raffaelli, D. G., Paterson, D. M., White, P. C. L., and Pierce, G. J. (2006). Introduction. Mar. Ecol. Prog. Ser. 311, 175-178. doi: 10.3354/meps311175

Spencer, M., Birchenough, S. N. R., Mieszkowska, N., Robinson, L. A., Simpson, S. D., Burrows, M. T., et al. (2010). Temporal change in UK marine communities: trends or regime shifts? Mar. Ecol. 32, 10-24. doi: 10.1111/j.14390485.2010.00422.x

Stief, P. (2013). Stimulation of microbial nitrogen cycling in aquatic ecosystems by benthic macrofauna: mechanisms and environmental implications. Biogeosciences 10, 7829-7846. doi: 10.5194/bg-10-7829-2013
Suess, E. (1980). Particulate organic carbon flux in the oceans - surface productivity and oxygen utilization. Nature 288, 260-263. doi: 10.1038/288260a0

Sun, M.-Y., Lee, C., and Aller, R. C. (1993). Laboratory studies of oxic and anoxic degradation of chlorophyll-a in Long Island Sound sediments. Geochim. Cosmochim. Acta 57, 147-157. doi: 10.1016/0016-7037(93)90475-C

Teixeira, I. G., Crespo, B. G., Nielsen, T. G., and Figueiras, F. G. (2014). Stratification-mixing cycles and plankton dynamics in a shallow estuary (Limfjord, Denmark). J. Plankton Res. 36, 475-489. doi: 10.1093/plankt/fbt107

Thrush, S. F., Hewitt, J. E., Gibbs, M., Lundquist, C., and Norkko, A. (2006). Functional role of large organisms in intertidal communities: community effects and ecosystem function. Ecosystems 9, 1029-1040. doi: 10.1007/s10021-0050068-8

Valdemarsen, T., and Kristensen, E. (2010). Degradation of dissolved organic monomers and short-chain fatty acids in sandy marine sediment by fermentation and sulfate reduction. Geochim. Cosmochim. Acta 74, 1593-1605. doi: 10.1016/j.gca.2009.12.009

Valdemarsen, T., Quintana, C. O., Kristensen, E., and Flindt, M. R. (2014). Recovery of organic-enriched sediments through microbial degradation: implications for eutrophic estuaries. Mar. Ecol. Prog. Ser. 503, 41-58. doi: 10.3354/ meps 10747

Valdemarsen, T., Wendelboe, K., Egelund, J. T., Kristensen, E., and Flindt, M. R. (2011). Burial of seeds and seedlings by the lugworm Arenicola marina hampers eelgrass (Zostera marina) recovery. J. Exp. Mar. Biol. Ecol. 410, 45-52. doi: 10.1016/j.jembe.2011.10.006

van Nes, E. H., Amaro, T., Scheffer, M., and Duineveld, G. C. A. (2007). Possible mechanisms for a marine benthic regime shift in the North Sea. Mar. Ecol. Prog. Ser. 330, 39-47. doi: 10.3354/meps330039

Viitasalo-Frösén, S., Laine, A. O., and Lehtiniemi, M. (2009). Habitat modification mediated by motile surface stirrers versus semi-motile burrowers: potential for a positive feedback mechanism in a eutrophied ecosystem. Mar. Ecol. Prog. Ser. 376, 21-32. doi: 10.3354/meps07788

Volkenborn, N., and Reise, K. (2006). Lugworm exclusion experiment: Responses by deposit feeding worms to biogenic habitat transformations. J. Exp. Mar. Biol. Ecol. 330, 169-179. doi: 10.1016/j.jembe.2005.12.025

Wendelboe, K., Egelund, J. T., Flindt, M. R., and Valdemarsen, T. (2013). Impact of lugworms (Arenicola marina) on mobilization and transport of fine particles and organic matter in marine sediments. J. Sea Res. 76, 31-38. doi: 10.1016/j.seares.2012.10.013

Wenzhöfer, F., and Glud, R. N. (2004). Small-scale spatial and temporal variability in coastal benthic $\mathrm{O}_{2}$ dynamics: effects of fauna activity. Limnol. Oceanogr. 49, 1471-1481. doi: 10.4319/lo.2004.49.5.1471

Ysebaert, T., Fettweis, M., Meire, P., and Sas, M. (2005). Benthic variability in intertidal soft-sediments in the mesohaline part of the Schelde estuary. Hydrobiologia 540, 197-216. doi: 10.1007/s10750-004-7144-5

Zipperle, A., and Reise, K. (2005). Freshwater springs on intertidal sand flats cause a switch in dominance among polychaete worms. J. Sea Res. 54, 143-150. doi: 10.1016/j.seares.2005.01.003

Conflict of Interest Statement: The authors declare that the research was conducted in the absence of any commercial or financial relationships that could be construed as a potential conflict of interest.

Received: 05 June 2014; accepted: 02 September 2014; published online: 23 September 2014.

Citation: Kristensen E, Delefosse M, Quintana CO, Flindt MR and Valdemarsen T (2014) Influence of benthic macrofauna community shifts on ecosystem functioning in shallow estuaries. Front. Mar. Sci. 1:41. doi: 10.3389/fmars.2014.00041

This article was submitted to Marine Ecosystem Ecology, a section of the journal Frontiers in Marine Science.

Copyright (C) 2014 Kristensen, Delefosse, Quintana, Flindt and Valdemarsen. This is an open-access article distributed under the terms of the Creative Commons Attribution License (CC BY). The use, distribution or reproduction in other forums is permitted, provided the original author(s) or licensor are credited and that the original publication in this journal is cited, in accordance with accepted academic practice. No use, distribution or reproduction is permitted which does not comply with these terms. 